\title{
Assessment of Climate Variability among Seasonal Trends Using In Situ Measurements: A Case Study of Punjab, Pakistan
}

\author{
Alishbah Syed ${ }^{1,2,3}$, Xingpeng Liu ${ }^{1,2,3}$, Md Moniruzzaman ${ }^{4}\left(\mathbb{D}\right.$, Iman Rousta ${ }^{5,6} \oplus$, Warda Syed ${ }^{7}$, \\ Jiquan Zhang $1,2,3, * \mathbb{D}$ and Haraldur Olafsson ${ }^{8}$
}

1 Institute of Natural Disaster Research, School of Environmental Science, Northeast Normal University, Changchun 130024, China; alishuvasian002@gmail.com (A.S.); liuxp912@nenu.edu.cn (X.L.)

2 State Environmental Protection Key Laboratory of Wetland Ecology and Vegetation Restoration, Northeast Normal University, Changchun 130024, China

3 Key Laboratory for Vegetation Ecology, Ministry of Education, Changchun 130024, China

4 ASICT Division, Bangladesh Agricultural Research Institute, Gazipur-1701, Bangladesh; moniruzzaman1313ku@gmail.com

5 Department of Geography, Yazd University, Yazd 8915818411, Iran; irousta@yazd.ac.ir

6 Institute for Atmospheric Sciences-Weather and Climate, University of Iceland and Icelandic Meteorological Office (IMO), Bustadavegur 7, IS-108 Reykjavik, Iceland

7 Institute of Geology, University of the Punjab, Lahore 54590, Pakistan; syedawarda3456@gmail.com

8 Institute for Atmospheric Sciences-Weather and Climate, Department of Physics, University of Iceland and Icelandic Meteorological Office (IMO), Bustadavegur 7, IS-108 Reykjavik, Iceland; haraldur@vedur.is

* Correspondence: zhangjq022@nenu.edu.cn; Tel.: +86-0431-8916-5616

check for

updates

Citation: Syed, A.; Liu, X.;

Moniruzzaman, M.; Rousta, I.; Syed,

W.; Zhang, J.; Olafsson, $\mathrm{H}$.

Assessment of Climate Variability among Seasonal Trends Using In Situ Measurements: A Case Study of Punjab, Pakistan. Atmosphere 2021, 12, 939. https://doi.org/10.3390/ atmos12080939

Academic Editor: John Walsh

Received: 31 May 2021

Accepted: 17 July 2021

Published: 22 July 2021

Publisher's Note: MDPI stays neutral with regard to jurisdictional claims in published maps and institutional affiliations.

Copyright: (C) 2021 by the authors. Licensee MDPI, Basel, Switzerland. This article is an open access article distributed under the terms and conditions of the Creative Commons Attribution (CC BY) license (https:// creativecommons.org/licenses/by/ $4.0 /)$.

\begin{abstract}
This research assessed the changes in spatial patterns and the seasonal trends in temperature, precipitation, and relative humidity over 36 years (1979-2014) using Climate Forecast System Reanalysis (CFSR) datasets. The evaluation of climate deviations was the prime objective of this research. The augmented Dickey-Fuller Test (ADF) was used to scrutinize whether the data was either stationary or non-stationary. The results of the ADF test showed that all the datasets were found to be stationary at lag order 3 . To observe undulations in the time series data, trend analyses were done using Sen's slope (SS), Mann-Kendall (MK), and Cox and Stuart (CS) tests. For all the statistical analyses, we considered the $5 \%$ significance level $(\alpha=0.05)$ and $p<0.05$ to be statistically significant. We observed significant $(p<0.05)$ trends in spring (MAM) and autumn (SON) for minimum temperature $\left(\mathrm{T}_{\min }\right)$ in Punjab. We also noted a significant $(p<0.05)$ trend in precipitation during autumn (SON). Annually, all the variables showed a non-significant $(p>0.05)$ trend for Punjab, Pakistan, during the period 1979-2014. Climate variability, such as a decrease in precipitation, higher temperature, and relative humidity fluctuations, were the reasons for the imbalance in the sustainability of Punjab, Pakistan.
\end{abstract}

Keywords: climate variability; Mann-Kendall test; Sen's slope; Cox and Stuart; trend analysis; Augmented Dickey-Fuller test

\section{Introduction}

Globally, climate change has a profound impact on many areas due to the variability in temperature and precipitation. It has attracted significant attention from researchers during the past few decades [1]. Climate change has become an emerging issue in some regions in recent years. It was demonstrated by various researchers [2] that the recorded fluctuations in temperature, precipitation, and relative humidity in the current era happened not only because of natural phenomena but also due to anthropogenic activities. The global mean surface temperature (GMST) increased by approximately $0.72{ }^{\circ} \mathrm{C}$ during 1951-2012 [3]. Correspondingly, there was a $2 \%$ increase in the proportion of universal land precipitation [4]; variations in precipitation patterns have ultimately impacted Pakistan's water reserves and agriculture [5]. Being an agriculture-dependent country, Pakistan is 
under climate threat. The 2000s was known as the warmest decade, and 2016 was known to be the warmest year of the last century in Pakistan. During the past three decades, the observed $\mathrm{T}_{\text {mean }}$ ranged from 0.78 to $1.5^{\circ} \mathrm{C}$, and at the end of this century, it is estimated to be 2 to $4^{\circ} \mathrm{C}$ according to the warming trend of the climate [6-8]. Rising temperatures are expected to have a significant impact on arid and semi-arid research regions in Punjab, Pakistan, such as Nankana Sahib, Sialkot, Multan, and Gujranwala [9].

Furthermore, temperature, precipitation, and relative humidity are synchronized with nature and reveal homogenous changes. For instance, an enormous amount of calculations is available regarding climate variability, but temperature, precipitation, and relative humidity are consequential indicators. Their annual and seasonal changes can help to study the alterations in climate [10]. The increase in temperature (such as $\mathrm{T}_{\max }, \mathrm{T}_{\text {min }}$, and $\mathrm{T}_{\text {mean }}$ ) leads to changes in precipitation and land warming, causing climate variability [11-13]. To mitigate these effects, assessment and adaptive measures can be based on the analysis of time series trends [14].

Changes in climate patterns are becoming the cause of droughts. However, reports on the of drought fragility and its numerical appraisal are rare [15]. The convergence of climatic factors and anthropogenic activities is called risk assessment. Therefore, to intensify the rationality of impact assessments, the separation of the degrees of influence of different climatic variables is mandatory. Understanding the relationships between climate variability and anthropogenic activities is critical for forecasting future changes and understanding profound variations and procedures in climate systems [16]. In addition to anthropogenic activities, changes in natural phenomena, such as fewer monsoons, intensified and longer cycles of rains, sea-level rise, cyclones, and tropical storms, have created prolonged droughts in winter and have accelerated the climate system $[17,18]$.

Numerous studies have shown that climate change can cause harm to the accessibility of environmental resources, resulting in an imbalance in sustainability [19]. For example, due to global warming, some species are endangered with extinction [20] because the pressure from climate variability in the tropical forest area has been increasing [21]. The decline in water accessibility is depleting the natural water resources. The above changes are caused by changes in climatic factors (temperature, precipitation, and relative humidity). We explored all these variables in the current study. Establishing an equilibrium in environmental demand and supply under the current changing climate in a timely manner is an arduous task. Some researchers also found that the future climate variability will cause an increase in the persistence and intensity of weather events [22]; this might increase the challenges of environmental reserves in a negative way and, as a result, create an imbalance in ecological sustainability. According to the above-stated limitations, to check climate suitability, expertise-based approaches are frequently used. Multiple parameters, including temperature, precipitation, wind speed, drought, and solar radiation, are under consideration when figuring out the adequacy and usefulness of literature reviews and expert questionnaire surveys. To address these problems, and to understand possible movements in sustainability with climate change, an extensive selection of actions was applied in the past few years [23].

For underdeveloped countries, such as Pakistan, the natural climate is mainly at risk because of urbanization and industrialization. These nations are primarily agriculturedependent, where this sector is highly vulnerable to climate variability and does not have many sources to adjust to the changing circumstances. In this regard, in such countries, the identification of traditional changes in climate parameters is of prime importance where the pillar of the economy is the agriculture sector, such as in Pakistan. Pakistan is located in one of the regions experiencing a sudden temperature increase [24,25]. The early studies have specified changes in temperature in different parts of Pakistan, such as in the Indus basin, where a significant positive trend has been observed in temperature indices [26]. In contrast, in the northern part of the country, decreasing trends in $\mathrm{T}_{\max }, \mathrm{T}_{\min }$, and $\mathrm{T}_{\text {mean }}$ were identified [27]. For northern, northwestern, and northeastern regions, research on rainfall trend analysis has found an increasing bias in the annual rainfall [28]. 
In contrast, starting from the late 1990s, [29] reported a decrease in precipitation and a temperature rise for the many sub-basins in the Upper Indus Basin (UIB). The study used six atmospheric factors in the UIB to estimate the trends that were attributable to the deficiency in the availability of in situ monitoring. Further, through numerous studies in southern and central areas of Pakistan, a decreasing trend in annual rainfall was described [30]. So far, no comprehensive research has been performed related to the spatiotemporal trends of the temperature, precipitation, and relative humidity in various parts of Punjab, Pakistan, which is a highly important region for agriculture [24].

In comparison, the early studies generally did not focus much on the primary components of seasonal trends in climate variability. Many studies showed trends in climate change by using observed data. Using the MK test and Sen's slope estimator, much literature has identified the temperature fluctuations and precipitation levels in Punjab, Pakistan. A brief review of the climatic trend analysis in Punjab, Pakistan, using different variables is given in Table 1 . These studies have some limitations since they analyze only a small proportion of stations or focus on only one or two indicators. As such, it is difficult to comprehend their trends and spatial patterns. Further, most of the early studies used the MK test, which cannot identify the monotonic trends in long-run changes in climatic events.

The newness in current research is that SS and MK are used, along with the CS test, to analyze the temporal and spatial trends in temperature $\left(\mathrm{T}_{\max }, \mathrm{T}_{\min }, \mathrm{T}_{\text {mean }}\right)$, precipitation, and relative humidity in Punjab, Pakistan. The current study examined the spatiotemporal changes in temperature trends $\left(T_{\max }, T_{\min }, T_{\text {mean }}\right)$, precipitation, and relative humidity for 16 different stations in Punjab, Pakistan. The analysis of climate variability has recognized events in environmental systems that impose some severe threats to human well-being and sustainability [31]. Levin and Clark [32] determined some of the significant challenges and threats to sustainability. They elaborated that because of the current climatic variability, the responses to sustainability challenges are resulting in not conserving natural reserves for future generations but are strengthening adaptability in the ecosystem. Now the question is whether current management is sustainable under a changing climate and whether adjustments are needed [33]. The main objectives of this research were (1) to address the regional measurement of the seasonal trends in the climatic variability of Punjab, Pakistan, and (2) to identify the spatiotemporal heterogeneity in the climate fluctuations of Punjab, Pakistan, using weather stations.

Table 1. A comprehensive outline of the previous studies on the climatic trends of Punjab, Pakistan.

\begin{tabular}{|c|c|c|c|c|c|}
\hline Research & $\begin{array}{l}\text { Timescale and } \\
\text { Datasets }\end{array}$ & Study Area & Quality Control of Data & Method & Findings \\
\hline Iqbal and Ali [34] & $\begin{array}{l}\text { Annual (1981-2010) } \\
\text { and gauges }\end{array}$ & $\begin{array}{l}\text { Lahore, Murree, } \\
\text { Sialkot, Jhelum }\end{array}$ & $\begin{array}{c}\text { Percentile or quantile } \\
\text { method, statistical } \\
\text { distribution to sort and fit } \\
\text { the data into extreme events }\end{array}$ & $\begin{array}{l}\text { GEV distribution, } \\
\text { log-Pearson type III analysis, } \\
\text { and Gumbel distribution }\end{array}$ & $\begin{array}{c}\text { Daily } 100 \text { mm precipitation } \\
\text { and more were observed; } \\
\text { therefore new dams are } \\
\text { needed. }\end{array}$ \\
\hline Aslam et al. [35] & $\begin{array}{c}\text { Observed and } \\
\text { projected (past and } \\
\text { future) }(2011-2085) \\
\text { and gauges }\end{array}$ & Southern Punjab & $\begin{array}{l}\text { Climatic models and IPCC's } \\
\text { A2 and A1B scenarios }\end{array}$ & $\begin{array}{l}\text { GEVs distribution, CREAT } \\
\text { and GIS software }\end{array}$ & $\begin{array}{l}\text { Climate change risks } \\
\text { identified. }\end{array}$ \\
\hline $\begin{array}{l}\text { Khattak and Ali } \\
\text { [36] }\end{array}$ & $\begin{array}{c}\text { Annual, seasonal } \\
(1961-2014), \text { and } \\
\text { gauges }\end{array}$ & Punjab & TFPW approach used in data & MK test and Sen's slope & $\begin{array}{l}\text { SON and DJF seasons } \\
\text { showed the most significant } \\
\text { changes of all. }\end{array}$ \\
\hline Salma et al. [37] & $\begin{array}{l}\text { Decadal (1976-2005) } \\
\text { and gauges }\end{array}$ & $\begin{array}{l}30 \text { stations of } \\
\text { Pakistan }\end{array}$ & Not mentioned & ANOVA, Dunnett T3 & $\begin{array}{l}\text { Rainfall showed a } \\
\text { decreasing trend all over } \\
\text { Pakistan. }\end{array}$ \\
\hline$\underset{[38]}{\text { Jahangir et al. }}$ & $\begin{array}{c}\text { Seasonal, annual } \\
\text { (1979-2013), and } \\
\text { (ECMWF) } \\
\text { (ERA-Interim) }\end{array}$ & $\begin{array}{l}\text { Eight tehsils of } \\
\text { Punjab }\end{array}$ & Not mentioned & Regression, MK test & $\mathrm{T}_{\min }$ had no annual trend. \\
\hline Abbas [39] & $\begin{array}{l}\text { Daily (1981-2010) and } \\
\text { gauges }\end{array}$ & $\begin{array}{l}\text { Sargodha, Multan, } \\
\text { Faisalabad, } \\
\text { Bahawalnagar, } \\
\text { Rawalpindi }\end{array}$ & $\begin{array}{l}13 \text { temperature indices } \\
\text { concerning semi-arid } \\
\text { environments analyzed } \\
\text { using RClimDex }\end{array}$ & $\begin{array}{l}\text { Mann-Kendall test, Sen's } \\
\text { slope }\end{array}$ & $\begin{array}{c}\text { Overall warming in regions, } \\
\text { as depicted by significant } \\
\text { trends in the temperature } \\
\text { patterns }\end{array}$ \\
\hline
\end{tabular}


Table 1. Cont.

\begin{tabular}{|c|c|c|c|c|c|}
\hline Research & $\begin{array}{l}\text { Timescale and } \\
\text { Datasets }\end{array}$ & Study Area & Quality Control of Data & Method & Findings \\
\hline Li et al. [40] & $\begin{array}{c}\text { Monthly, annual } \\
\text { (1980-2011), and } \\
\text { gauges }\end{array}$ & Southern Punjab & Not mentioned & SimCLIM & $\begin{array}{l}\text { Sustainable management of } \\
\text { climatic risk required. }\end{array}$ \\
\hline Abbas et al. [41] & $\begin{array}{c}\text { Daily, monthly, } \\
\text { annual (1981-2010), } \\
\text { and gauges }\end{array}$ & $\begin{array}{l}\text { Five cities of } \\
\text { Punjab }\end{array}$ & $\begin{array}{l}\text { RClimDex used to assure } \\
\text { that data was error free }\end{array}$ & MK test, Sen's slope & $\begin{array}{l}\text { No spatio-temporal trends } \\
\text { were depicted. }\end{array}$ \\
\hline $\begin{array}{c}\text { Nashwan et al. } \\
{[24]}\end{array}$ & $\begin{array}{l}\text { Annual, seasonal } \\
\text { (1967-2017), and } \\
\text { gauges }\end{array}$ & Punjab & $\begin{array}{l}\text { For the removal of } \\
\text { autocorrelation, they used a } \\
\text { pre-whitening procedure }\end{array}$ & $\begin{array}{l}\text { Mann-Kendall, Sen's slope, } \\
\text { IDW }\end{array}$ & Spring was the warm season. \\
\hline
\end{tabular}

\section{Materials and Methods}

\subsection{Study Area}

The study area of Punjab is the 2nd largest province of Pakistan among the four provinces (Balochistan, Khyber Pakhtunkhwa, Punjab, and Sind) and is geographically located in between $24-37^{\circ} \mathrm{N}$ and $62-75^{\circ} \mathrm{E}$ (Figure 1 ). Climatologically, most of Punjab is arid and semi-arid, having a finite spatio-temporal variability in the climate indicators, including precipitation; relative humidity; and maximum, mean, and minimum temperatures [42]. More than half (59\%) of the annual precipitation is because of monsoons, which are the supreme hydro-meteorological reserve of Punjab. The elevation of Punjab varies between 71-2193 m. From March to May (spring), the temperature rises, and this situation remains until summer [38]. Furthermore, the monsoons are expected to arrive in Punjab at the end of May, although weather conditions have shown unpredictable patterns since the early 1970s.

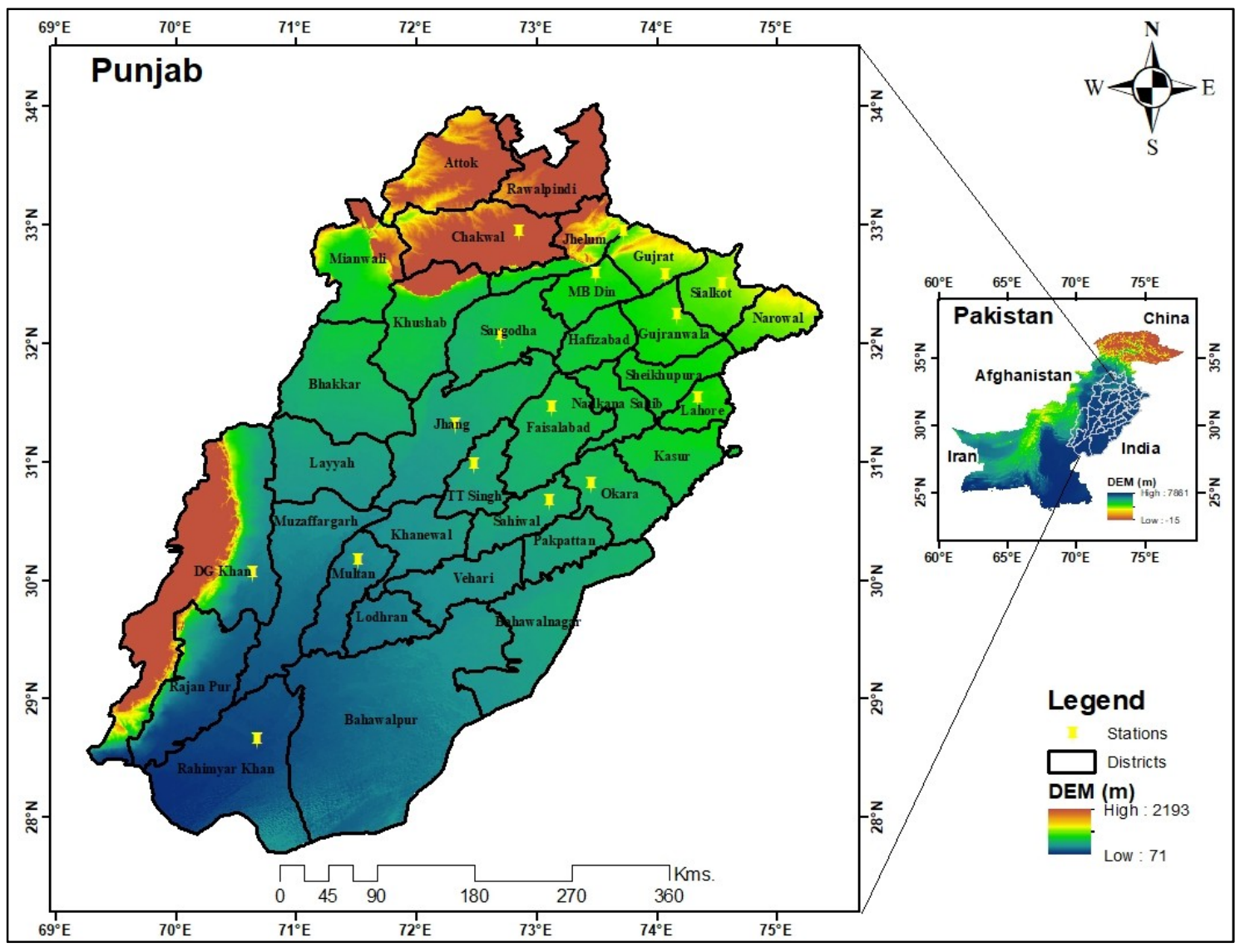

Figure 1. The map of Punjab, Pakistan, showing the districts with 16 CSFR stations. 
During 1970-2001 in Punjab, Pakistan, the average annual $\mathrm{T}_{\max }$ was generally between 29.3 and $31.9^{\circ} \mathrm{C}$; on the other hand, the average yearly $\mathrm{T}_{\min }$ was between 16.3 and $18.2^{\circ} \mathrm{C}$ [43]. The rainfall in Punjab is widespread, which is generally connected to monsoon winds. The highest rainfall was received by the rain-fed (Barani) zone and the irrigated plains, marginal land, and Thal region [44]. Altogether, the climate is arid and has an annual precipitation of $100 \mathrm{~mm}$ in the south, $600 \mathrm{~mm}$ in the northwest, and $1000 \mathrm{~mm}$ at the northeastern boundary. The yearly primary precipitation is from the monsoon season from June till September, leading to flooding [45]. The temperature generally ranges between $-2{ }^{\circ} \mathrm{C}$ and $45^{\circ} \mathrm{C}$, but it can go as high as $47^{\circ} \mathrm{C}$ in the summer season, and it can as low as $-5^{\circ} \mathrm{C}$ during the winter season.

\subsection{Land-Cover Type (LC Type)}

To determine the progressing changes, the LC mapping for a region is an important task. Land-cover mapping helps us discover whether a specific sector, i.e., agriculture or urban, requires proper planning and management. Land-cover descriptions and the area occupied by each LC type for Punjab, Pakistan, are available in Table 2. Punjab, Pakistan, has 5 major rivers: Ravi, Sutlej, Jhelum, Bias, and Chenab. These rivers carry sediments that arise due to swift erosion from the Himalayan south mountains into the Indus River Delta and then into the Arabian Sea [46]. The LC type data of Punjab, Pakistan, that were identified from MODIS (MCD12Q1) images using IGBP classifications are shown in Figure 2 and Table 2.

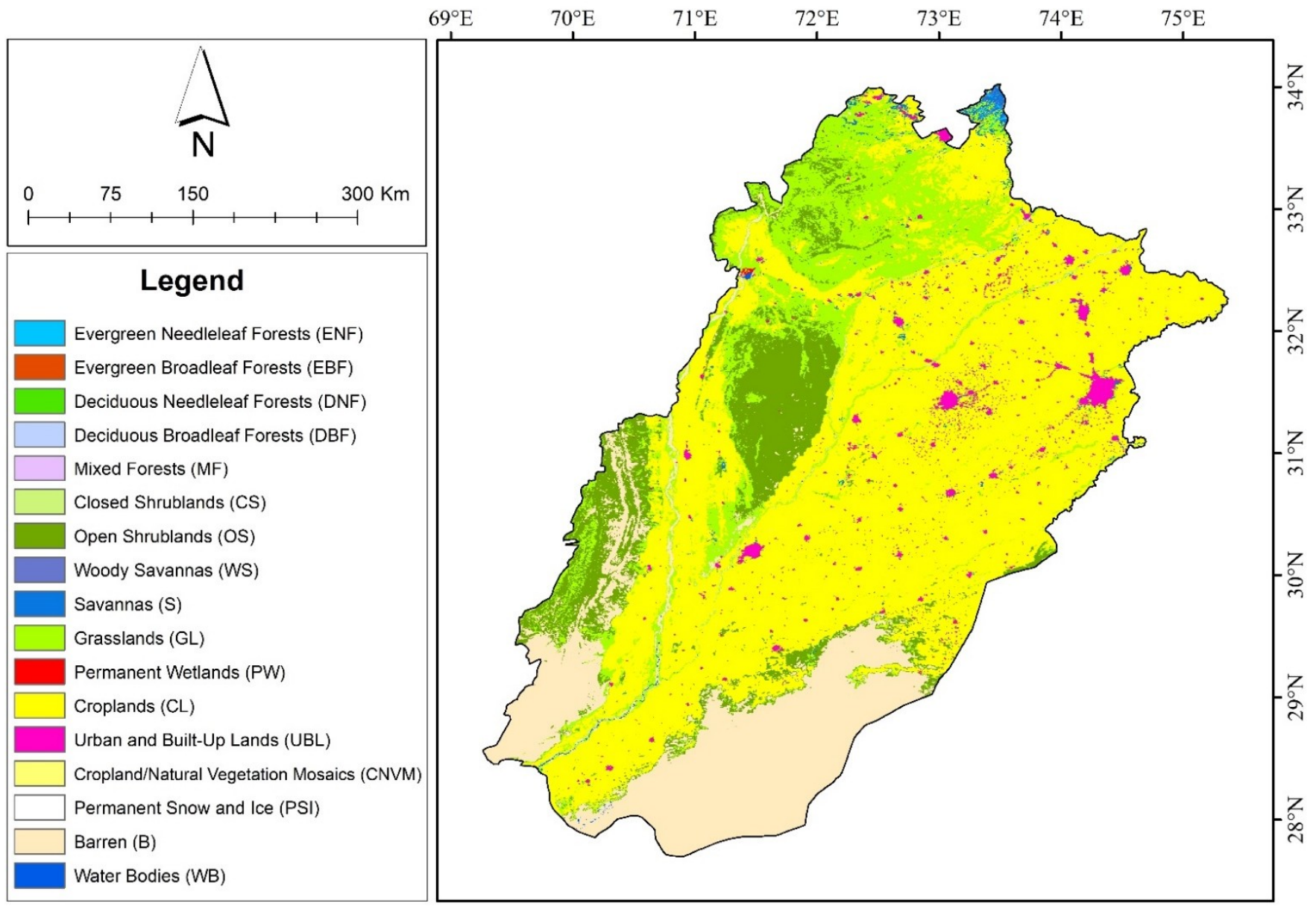

Figure 2. Land-cover type map of Punjab, Pakistan, that was identified from MODIS (MCD12Q1) images using IGBP classifications. 
Table 2. Land-cover types of Punjab, Pakistan, that were identified from MODIS (MCD12Q1) images using IGBP classifications $[47,48]$.

\begin{tabular}{cc}
\hline LC Type & Area $\mathbf{( k m}^{\mathbf{2}} \mathbf{~}$ \\
\hline Evergreen Needleleaf Forests (ENF) & 105.3 \\
Evergreen Broadleaf Forests (EBF) & 3.5 \\
Deciduous Needle leaf Forests (DNF) & 0.0 \\
Deciduous Broadleaf Forests (DBF) & 0.0 \\
Mixed Forests (MF) & 0.0 \\
Closed Shrublands (CS) & 3.5 \\
Open Shrublands (OS) & $21,375.8$ \\
Woody Savannas (WS) & 70.6 \\
Savannas (S) & 1357.7 \\
Grasslands (GL) & $28,215.8$ \\
Permanent Wetlands (PW) & 64.5 \\
Croplands (CL) & $115,836.3$ \\
Urban and Built-Up Lands (UBL) & 3882.7 \\
Permanent Snow and Ice (PSI) & 64.3 \\
Barren (B) & 0.0 \\
Water Bodies (WB) & $34,208.6$ \\
\hline
\end{tabular}

\subsection{Data Source}

This study used data from 16 stations in Punjab, Pakistan, to assess the climate vulnerability. The Climate Forecast System Reanalysis (CSFR) data were used in this research. Daily data from 1979 to 2014 for 16 stations were downloaded from the Global Weather data for SWAT (https:/ / globalweather.tamu.edu/, last access: 10 September 2014) website. It was used to investigate the long-run variability in the seasonal and annual maximum, minimum, and mean temperature, precipitation, and relative humidity. The studied stations are located in various irrigation zones of Punjab, Pakistan, and daily data for 5 variables were used in the current study, as shown in Table 3. We selected these 16 stations due to their popularity and the completeness of records based on their spatio-temporal coverage, history, and uniformity. The considered seasons are described as follows: winter (December, January, February (DJF)), spring (March, April, May (MAM)), summer (June, July, August (JJA)), and autumn (September, October, November (SON)) [49].

Table 3. Information about the studied stations in Punjab, Pakistan.

\begin{tabular}{cccc}
\hline Station & Latitude $\left(\mathbf{N}^{\circ}\right)$ & Longitude $\left.\mathbf{( E}^{\circ}\right)$ & Altitude $(\mathbf{m})$ \\
\hline Chakwal & 32.94 & 72.81 & 518 \\
DG Khan & 30.13 & 70.62 & 122 \\
Faisalabad & 31.46 & 73.13 & 172 \\
Gujranwala & 32.32 & 74.15 & 225 \\
Gujrat & 32.62 & 74.06 & 230 \\
Jhang & 31.37 & 72.18 & 156 \\
Jhelum & 32.94 & 73.75 & 222 \\
Khanpur & 28.65 & 70.62 & 76 \\
Lahore & 31.69 & 74.37 & 205 \\
MB Din & 32.62 & 73.43 & 208 \\
Multan & 30.13 & 71.56 & 118 \\
Okara & 30.75 & 73.43 & 164 \\
Sahiwal & 30.75 & 73.12 & 160 \\
Sargodha & 32.00 & 72.81 & 177 \\
Sialkot & 32.62 & 74.68 & 255 \\
TT Singh & 30.06 & 72.48 & 163 \\
\hline
\end{tabular}




\section{Used Techniques}

For the trend analysis, three types of techniques were used in this study. Before the Mann-Kendall (MK), Sen's slope estimator, and CS methods can be used, it is mandatory to test whether the time series datasets are stationary. To analyze the stationarity of the datasets, there are many methods, but in this study, we used the augmented Dickey-Fuller test (ADF) for $\mathrm{T}_{\max }, \mathrm{T}_{\min }, \mathrm{T}_{\text {mean }}$, precipitation, and relative humidity data series in RStudio. Because the results for the unit root testing were reliable, the ADF test was a good option, as it can perform a more significant number of observations, especially in the case of a time series [50]. Due to its simple assembly and feasibility, it is the most regularly used test. Furthermore, the trends analysis was done using the MK test, Sen's slope estimator, and CS methods. Rather than comparing the data values themselves, the MK test compares the similar magnitudes of the sample datasets [51].

One boon of this test is that there is no need for the data to fit a certain distribution. A second benefit of the test is available, which is its low sensitivity toward quick breaks because of an inhomogeneous time series [2,52]. CS [53] defined it as a little powerful test, but it is very rigorous regarding trend analyses. The method we discussed is based on the binomial distribution, and it can be applied to an extensive range of conditions. This method was used to verify the significance of the trend and establish the magnitudes of variability and directions of changes. The technique is more helpful for detecting magnitude and direction when the Mann-Kendall test is used [54]. SS regulates the magnitude of a present trend [55]. In this study, these techniques were used to assess the patterns of the variables and their significance levels in Punjab, Pakistan. Moreover, for investigating the atmospheric dynamics of Punjab during the study period, geopotential height data of $850 \mathrm{hPa}$ for $1979-2014$ and latitudes of $0-60^{\circ} \mathrm{N}$ and longitude $40-100^{\circ} \mathrm{E}$ were retrieved from NCEP/NCAR and analyzed. This dataset was developed in a three-state reanalysis with a spatial resolution of $2.5^{\circ} \times 2.5^{\circ}$ latitude by longitude and a $4 \mathrm{~h}$ temporal resolution $(00,06,12$, and 18$)$.

\subsection{Augmented Dickey-Fuller (ADF) Test}

Through ordinary least squares (OLS) regression models, the Dickey-Fuller unit root tests incorporate a linear trend. Suppose the following AR (1) model [56]:

$$
X_{t}=\rho X_{t-1}+\rho_{t}, t=1 ; 2 ; \ldots ; n
$$

where $X_{0}=0,|\rho| \leq 1$ :

$$
\hat{\rho}=\left[\sum_{t=2}^{n} X_{t-1}^{2}\right]^{-1} \sum_{t=2}^{n} X_{t} X_{t-1}
$$

The statistic to check the null hypothesis, $p=1$, depends on a common OLS (ordinary least squares) $t$-test:

$$
\frac{t=\hat{\rho}-1}{\hat{Y}_{\hat{\rho}}}
$$

The augmented Dickey-Fuller (ADF) stationarity test was first proposed by [57] and modified by [58] and is used to detect whether the data has a unit root. The augmentation can be done in the standard autoregressive unit root test (referred to as the ADF test) to assist general AR (p, q) models with unspecified orders [56]. The DF procedure, which was organized for the auto-regression presentations of familiar orders, remained asymptotically viable for a common ARIMA $(p, 1, q)$ approach for $p$ and $q$ that are of unspecified orders.

\subsection{Mann-Kendell (MK) Trend Test}

In the current research, we used the Mann-Kendall (MK) test to undertake trend analyses. This test is also known as a distribution-free (non-parametric) test. It is rigorous regarding missing values and is less sensitive to the swift breakpoints [59]. In hydrological or metrological temporal data series, it has a universal use since it can detect whether 
a trend is available in either dataset [60]. Nevertheless, the test is prone to the serial correlation that may influence the results [61]. In the present research, before proceeding to MK to probe the analytical magnitude and significance of the trends in the datasets, the sequential correlation approach was employed for the series.

MK test was used to analyze the changes and whether they were significant. The MK test can be applied to detect trend analysis because it only requires the assumption of independent datasets, though the chance of a significance level in the trend can be increased by the availability of serial autocorrelation in datasets [62]. Past research expressed that significant trends with time are also sensitive toward autocorrelations regarding whether the concerned datasets have short- or long-term autocorrelation in them; as [63] explained, MK trend test analysis is strongly affected through long-term autocorrelations because of the inter-decadal nature of climate variability. Hence, because of the long-term flux in time series datasets generated by natural climate variability, the MK trend test escalates the significance of a trend [15].

$$
\begin{gathered}
S=\sum_{i=1}^{n-1} \sum_{j=i+1}^{n} \operatorname{sgn}(X j-X i) \\
\operatorname{sgn}(X i-X i)=\left\{\begin{array}{c}
+1 \text { if }(X j-X i)>0 \\
0 \text { if }(X j-X i)=0 \\
-1 \text { if }(X j-X i)<0 \\
E(S)=0
\end{array}\right. \\
\operatorname{Var}(S)=\frac{1}{18}\left[n(n-1)(2 n+5)-\sum_{i=1}^{M} T i(T i-1)(2 T i+5)\right] \\
Z=\left\{\begin{array}{c}
\frac{(S-1)}{\sqrt{\operatorname{Var}(S)}}, S>0 \\
0, S=0 \\
\frac{(S+1)}{\sqrt{\operatorname{Var}(S)}}, S<0
\end{array}\right.
\end{gathered}
$$

\subsection{Sen's Slope (SS)}

SS, which was proposed by [64], is a non-parametric trend test for computing the slope for a trend in time series data [28]. When there is a need to know the magnitude of a change in varying data, then SS is also used to determine whether a linear trend is present in the dataset, where the slope estimates of the dataset are quantified using Equation (8):

$$
T_{\text {med }}=\frac{X_{j}-X_{i}}{j-i}
$$

In this equation, at times $j$ and $i$, the data values are represented by $X_{j}$ and $X_{i}$, respectively. Furthermore:

$$
Q_{\text {med }}= \begin{cases}T_{\frac{(N+1)}{2}} & N \text { is odd } \\ 2^{-1}\left(T_{\frac{N}{2}}+T_{\frac{(N+2)}{2}}\right) & N \text { is even }\end{cases}
$$

\subsection{Cox and Stuart (CS) Test}

The foundation of the $\mathrm{CS}$ test is the null hypothesis $\left(\mathrm{H}_{\mathrm{O}}\right)$ and the alternative hypothesis $\left(\mathrm{H}_{\mathrm{a}}\right)$. The null hypothesis represents the belief that no monotonic trend exists in the datasets, in contrast with the alternative hypothesis. CS [53] presents a whole system to check whether upward or downward trends are present, and it is not mandatory that they must be linear, but they can easily convey a comprehensive trend in the observed data. The CS test is also a member of the non-parametric family, just like the Mann-Kendall test. The CS test has limited use but is very powerful for trend analysis in datasets [65]. The CS test 
is applied to numerous circumstances to understand the trueness of the obtained values, where the substructure of this technique is the binomial distribution. This test can be used to find the trend in an independent time series dataset. It should have lower power than the MK test $[66,67]$. The main purpose of using this test in the current study was to identify the monotonical tendencies of the variables and their variability. More details are available in the study by Conover [68].

\section{Results}

An indication of the long-term variability in precipitation is concerned with the change in ocean patterns, with a smaller effect from anthropogenic activities. Still, the main effect is from atmospheric circulation [69]. The differential temporal behavior of rainfall trends is associated with its spatial distribution $[70,71]$. The non-parametric tests used in this study only need the data to be independent and include all outliers in the data series [38,72,73].

In the current research, the daily data for five variables were taken from 16 different stations for 1979-2014. For the accuracy of the recorded datasets, the prime concern was exploring the missing values and finding suitable replacements. Ergo, to verify the quality of the data [74], missing values were identified and then fixed by using Jupyter Notebook 6.0.3 of the Anaconda Navigator script. Its method was based on checking the monthly records and then taking the average values of the upper and lower years of similar months for a period [75]. To check whether the data was stationary or non-stationary, we performed an ADF test in R-Studio. After passing the data through the series, we concluded that our data was stationary at lag order 3, which is shown in Table 4. Subsequently, the three techniques described in the methodology were used to evaluate the variables for the period 1979-2014 via statistical analysis of station data using the MK, CS, and SS tests. By contrasting the critical values with computed Z-values, the decision for the CS test was made [76]. The results of the trends analyses to determine the $T_{\max }$ data series indicated no annual trend for the Punjab province (Tables 5 and 6).

Table 4. Stationarity test results for the datasets from Punjab, Pakistan, over the period 1979-2014.

\begin{tabular}{|c|c|c|c|c|}
\hline Variable & Period & Dickey-Fuller Statistics & Lag Order & $p$-Value \\
\hline \multirow{5}{*}{ Relative Humidity } & Annual & -1.0683 & 3 & 0.9138 \\
\hline & Spring & 0.71636 & 3 & 0.99 \\
\hline & Summer & -1.6563 & 3 & 0.7069 \\
\hline & Autumn & -1.3561 & 3 & 0.8237 \\
\hline & Winter & -1.455 & 3 & 0.7852 \\
\hline \multirow{5}{*}{$\mathrm{T}_{\min }$} & Annual & -2.8262 & 3 & 0.2517 \\
\hline & Spring & -1.9056 & 3 & 0.6099 \\
\hline & Summer & -2.4213 & 3 & 0.4092 \\
\hline & Autumn & -2.6111 & 3 & 0.3354 \\
\hline & Winter & -3.458 & 3 & 0.06482 \\
\hline \multirow{5}{*}{ Precipitation } & Annual & -0.58289 & 3 & 0.9707 \\
\hline & Spring & -0.25562 & 3 & 0.987 \\
\hline & Summer & -0.68024 & 3 & 0.9625 \\
\hline & Autumn & -1.565 & 3 & 0.7424 \\
\hline & Winter & -3.2846 & 3 & 0.09003 \\
\hline \multirow{5}{*}{$\mathrm{T}_{\max }$} & Annual & -1.7115 & 3 & 0.6854 \\
\hline & Spring & -0.26229 & 3 & 0.9867 \\
\hline & Summer & -1.5884 & 3 & 0.7333 \\
\hline & Autumn & -2.7758 & 3 & 0.2713 \\
\hline & Winter & -2.4332 & 3 & 0.4046 \\
\hline \multirow{5}{*}{$\mathrm{T}_{\text {mean }}$} & Annual & -1.889 & 3 & 0.6163 \\
\hline & Spring & -0.64877 & 3 & 0.9651 \\
\hline & Summer & -1.5766 & 3 & 0.7379 \\
\hline & Autumn & -2.8736 & 3 & 0.2332 \\
\hline & Winter & -3.0796 & 3 & 0.1531 \\
\hline
\end{tabular}


Table 5. Summary of the significance and magnitude of statistical tests of Punjab, Pakistan, over the period 1979-2014.

\begin{tabular}{|c|c|c|c|c|c|c|c|c|c|c|c|}
\hline \multirow[t]{2}{*}{ Method } & \multirow[t]{2}{*}{ Datasets } & \multicolumn{2}{|c|}{ Annual } & \multicolumn{2}{|c|}{ Spring } & \multicolumn{2}{|c|}{ Summer } & \multicolumn{2}{|c|}{ Autumn } & \multicolumn{2}{|c|}{ Winter } \\
\hline & & $\mathrm{Z}$ & $p$-Value & $\mathrm{Z}$ & $p$-Value & $\mathbf{Z}$ & $p$-Value & $\mathbf{Z}$ & $p$-Value & $\mathbf{Z}$ & $p$-Value \\
\hline \multirow{5}{*}{ CS } & $\mathrm{T}_{\max }$ & 0.57735 & 0.5637 & 1.1547 & 0.2482 & 0 & 1 & 0 & 1 & 1.1547 & 0.2482 \\
\hline & $\mathrm{T}_{\min }$ & 0.57735 & 0.5637 & 1.1547 & 0.2482 & 1.1547 & 0.2482 & 1.7321 & 0.08326 & 1.1547 & 0.2482 \\
\hline & $\mathrm{T}_{\text {mean }}$ & 0.57735 & 0.5637 & 1.7321 & 0.08326 & 0.57735 & 0.5637 & 0 & 1 & 1.1547 & 0.2482 \\
\hline & Precipitation & 0 & 1 & 0.57735 & 0.5637 & 0 & 1 & 2.3094 & $0.02092 *$ & 1.1547 & 0.2482 \\
\hline & Relative Humidity & 0.57735 & 0.5637 & 1.1547 & 0.2482 & 1.1547 & 0.2482 & 0.57735 & 0.5637 & 0.57735 & 0.5637 \\
\hline \multirow{5}{*}{ Sen's Slope } & $\mathrm{T}_{\max }$ & 0.34052 & 0.7335 & 1.5664 & 0.1173 & -1.7026 & 0.08864 & -0.46315 & 0.6433 & 1.6209 & 0.105 \\
\hline & $\mathrm{T}_{\min }$ & 1.6209 & 0.105 & 2.1385 & $0.03248 *$ & -1.1305 & 0.2583 & 2.7517 & $0.005929 *$ & 0.66742 & 0.5045 \\
\hline & $\mathrm{T}_{\text {mean }}$ & 0.83087 & 0.406 & 1.8933 & 0.05832 & -1.3212 & 0.1864 & 0.51764 & 0.6047 & 0.93984 & 0.3473 \\
\hline & Precipitation & 1.1033 & 0.2699 & -0.85812 & 0.3908 & 1.9478 & 0.05144 & 2.5743 & $0.01004 *$ & 0.28604 & 0.7748 \\
\hline & Relative Humidity & 0.28604 & 0.7748 & -0.83087 & 0.406 & 1.9478 & 0.05144 & 1.4167 & 0.1566 & -1.5392 & 0.1238 \\
\hline
\end{tabular}

(The asterisk "*" sign represents the presence of a significant trend in the datasets).

Table 6. Summary of the results showing significant increasing and decreasing trends in the annual and seasonal datasets using the Mann-Kendall (MK) test on 1979-2014 data.

\begin{tabular}{|c|c|c|c|c|c|}
\hline Variable & Period & $\mathrm{Z}$ & $p$-Value & Tau & Sen's Slope \\
\hline \multirow{5}{*}{$\mathrm{T}_{\max }$} & Annual & 0.34052 & 0.7335 & 0.0413 & 0.003785724 \\
\hline & Spring & 1.5664 & 0.1173 & 0.184127 & 0.05672601 \\
\hline & Summer & -1.7026 & 0.08864 & -0.2 & -0.04438865 \\
\hline & Autumn & -0.46315 & 0.6433 & -0.0555997 & -0.01289091 \\
\hline & Winter & 1.6209 & 0.105 & 0.1904762 & 0.02922854 \\
\hline \multirow{5}{*}{$\mathrm{T}_{\min }$} & Annual & 1.6209 & 0.105 & 0.1904762 & 0.01232204 \\
\hline & Spring & 2.1385 & 0.03248 * & 0.2507937 & 0.0295206 \\
\hline & Summer & -1.1305 & 0.2583 & -0.1333333 & -0.01047383 \\
\hline & Autumn & 2.7517 & 0.005929 * & 0.3224783 & 0.02990238 \\
\hline & Winter & 0.66742 & 0.5045 & $7.94 \times 10^{-2}$ & 0.005428902 \\
\hline \multirow{5}{*}{$\mathrm{T}_{\text {mean }}$} & Annual & 0.83087 & 0.406 & $9.84 \times 10^{-2}$ & 0.01043978 \\
\hline & Spring & 1.8933 & 0.05832 & 0.2222222 & 0.0432524 \\
\hline & Summer & -1.3212 & 0.1864 & -0.1555556 & -0.02431877 \\
\hline & Autumn & 0.51764 & 0.6047 & $6.20 \times 10^{-2}$ & 0.006427549 \\
\hline & Winter & 0.93984 & 0.3473 & 0.1111111 & 0.01771422 \\
\hline \multirow{5}{*}{ Precipitation } & Annual & 1.1033 & 0.2699 & 0.1301587 & 3.555487 \\
\hline & Spring & -0.85812 & 0.3908 & -0.1015873 & -0.5732461 \\
\hline & Summer & 1.9478 & 0.05144 & 0.2285714 & 3.216461 \\
\hline & Autumn & 2.5743 & 0.01004 * & 0.3015873 & 1.183146 \\
\hline & Winter & 0.28604 & 0.7748 & $3.49 \times 10^{-2}$ & 0.118801 \\
\hline \multirow{5}{*}{ Relative Humidity } & Annual & 0.28604 & 0.7748 & 0.0349 & 0.0000821 \\
\hline & Spring & -0.83087 & 0.406 & -0.0984127 & -0.000895091 \\
\hline & Summer & 1.9478 & 0.05144 & 0.2285714 & 0.00242869 \\
\hline & Autumn & 1.4167 & 0.1566 & 0.1667991 & 0.001914679 \\
\hline & Winter & -1.5392 & 0.1238 & -0.1809524 & -0.002038008 \\
\hline
\end{tabular}

(The asterisk "*" sign represents the presence of a significant trend in the datasets).

Meanwhile, at the seasonal scale, there was a significant trend shown through SS, which depicted a clear decreasing trend in precipitation in the summer season. The annual and seasonal trends analysis of $\mathrm{T}_{\max }, \mathrm{T}_{\min }, \mathrm{T}_{\text {mean }}$, precipitation, and relative humidity obtained using the MK, SS, and CS approaches are presented in Tables 5 and 6. The CS test indicated that all the variables were monotonic. The magnitudes of the statistically significant trends were determined using the MK test and Sen's slope estimator. These trend analysis tests were applied in two ways. First, they performed by taking the average values of the 16 stations, where results are shown in Tables 4-6. Second, the analysis was done for each of the 16 stations separately, where the results are represented in Figures 3-8. 


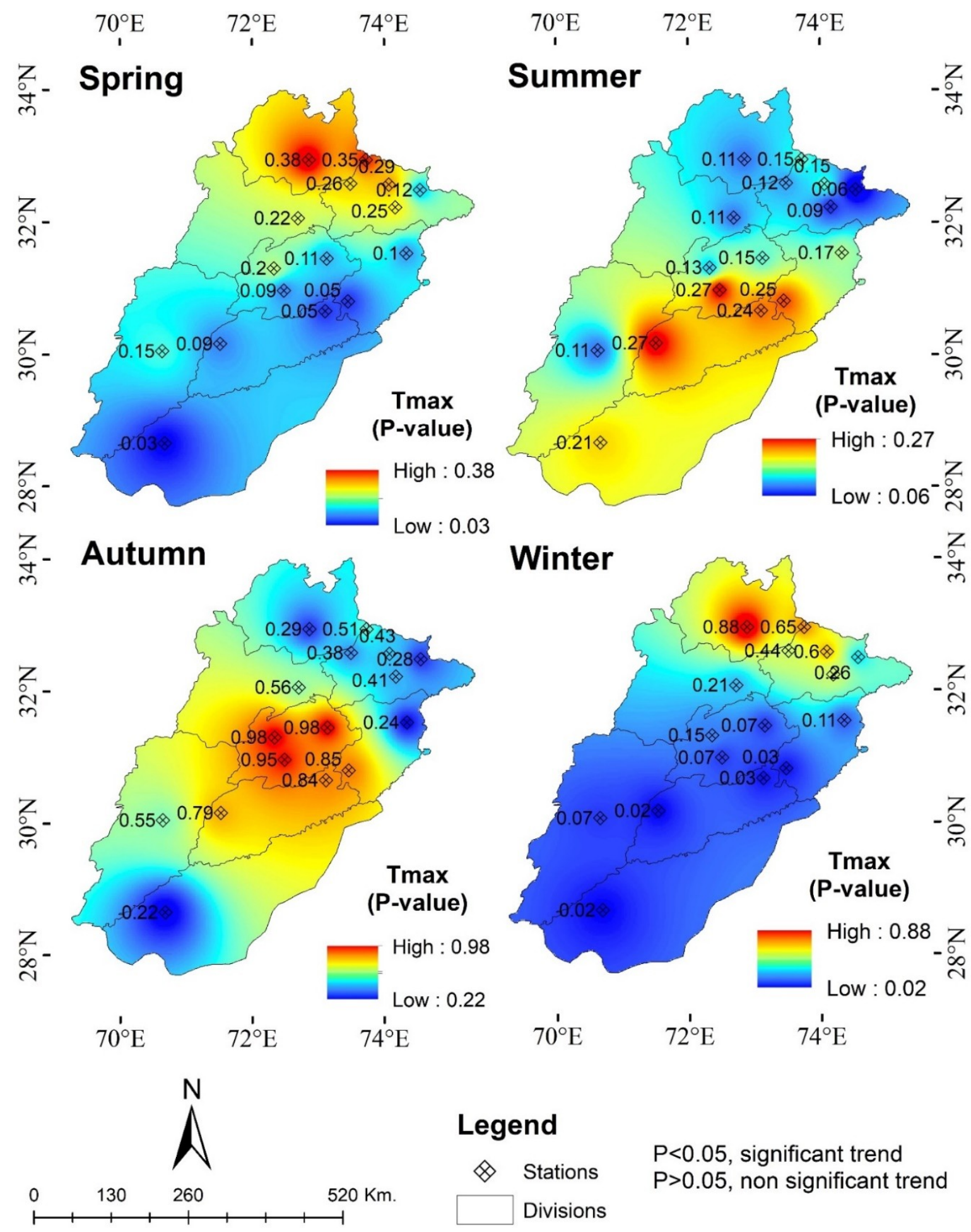

Figure 3. Seasonal $p$-values and the trends in $\mathrm{T}_{\max }\left({ }^{\circ} \mathrm{C}\right)$ of the 16 stations of Punjab, Pakistan, over the period 1979-2014. 

$70^{\circ} \mathrm{E}$
$74^{\circ} \mathrm{E}$
$70^{\circ} \mathrm{E}$
$72^{\circ} \mathrm{E}$
$74^{\circ} \mathrm{E}$

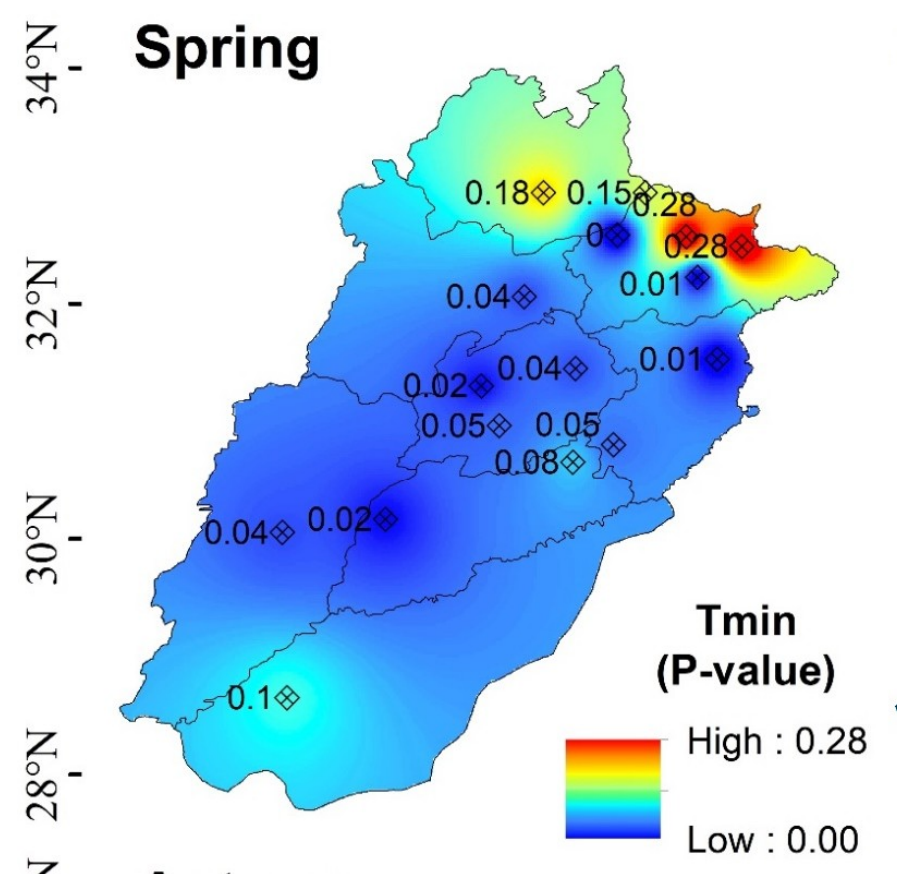

隹- Autumn

\section{Summer}
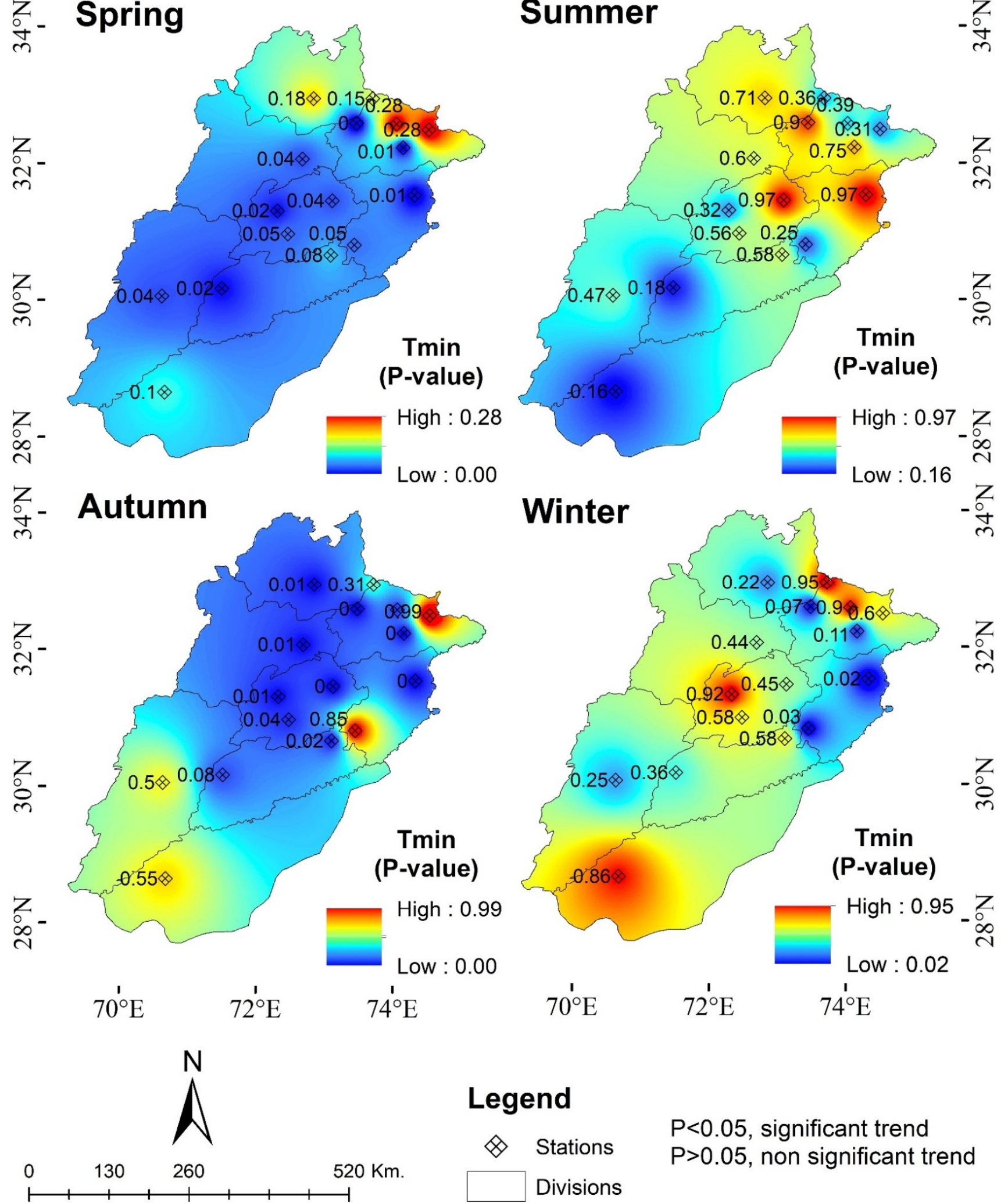

\section{Legend}

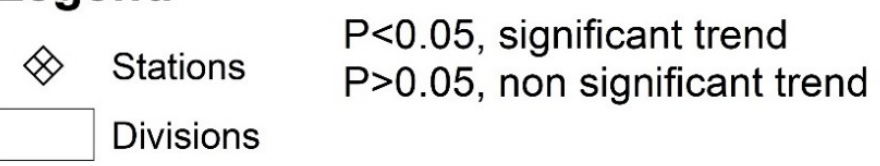

Figure 4. Seasonal $p$-values and the trends in $\mathrm{T}_{\min }\left({ }^{\circ} \mathrm{C}\right)$ of the 16 stations of Punjab, Pakistan, over the period $1979-2014$. 


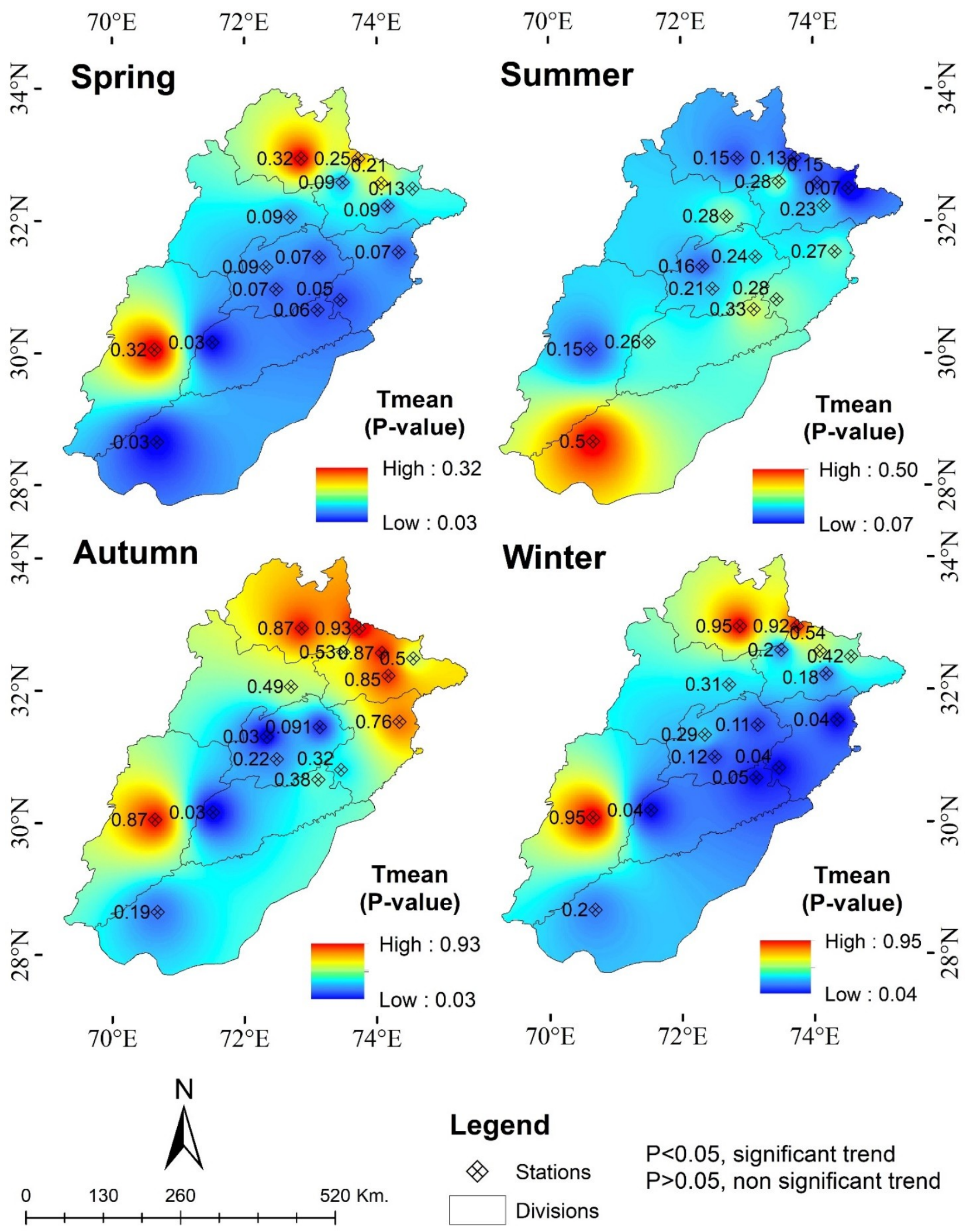

Figure 5. Seasonal $p$-values and the trends in $\mathrm{T}_{\text {mean }}\left({ }^{\circ} \mathrm{C}\right)$ of the 16 stations of Punjab, Pakistan, over the period 1979-2014. 


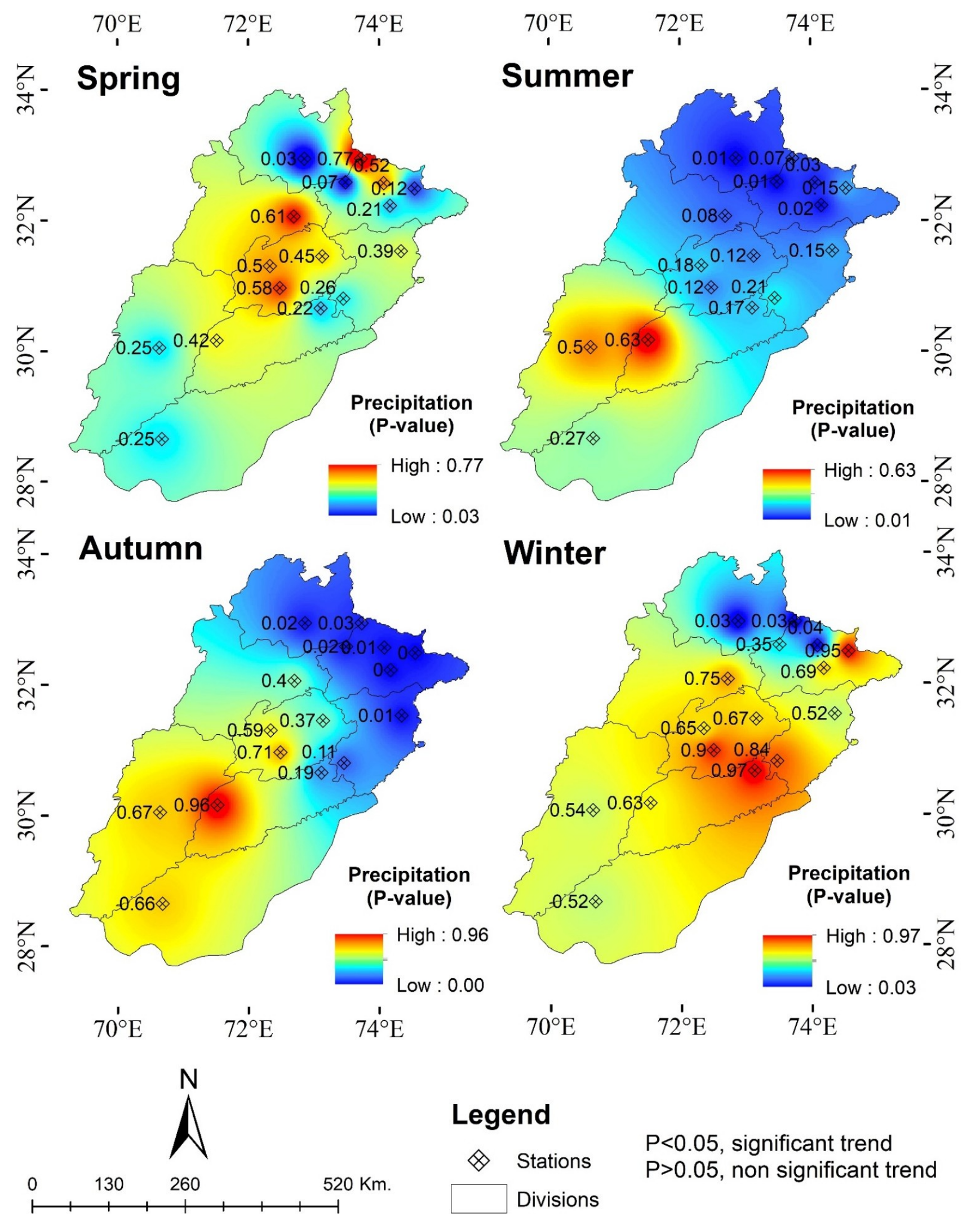

Figure 6. Seasonal $p$-values and the trends in precipitation $(\mathrm{mm})$ of the 16 stations of Punjab, Pakistan, over the period 1979-2014. 
$70^{\circ} \mathrm{E}$
Spring

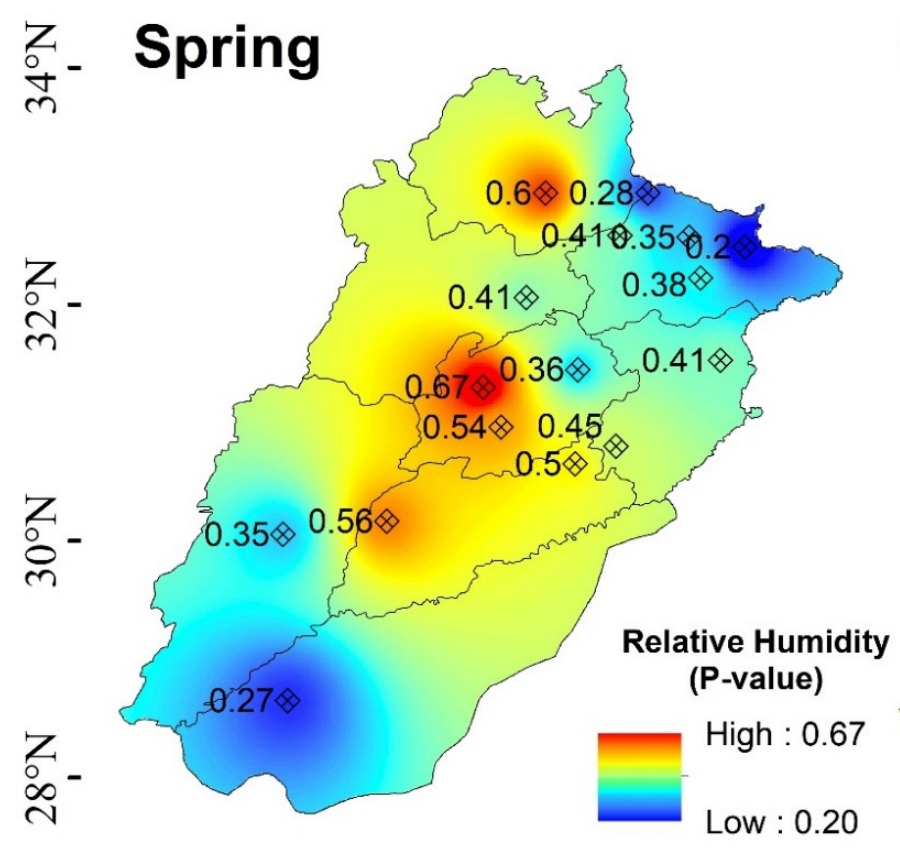

产- Autumn

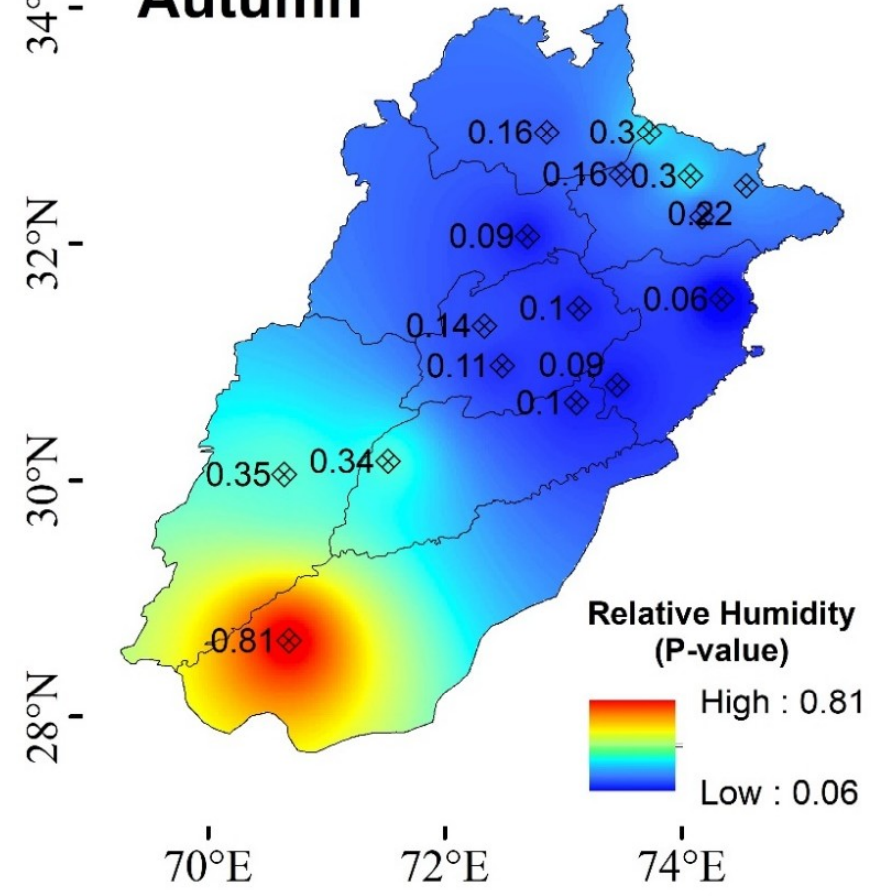

$70_{1}^{\circ} \mathrm{E} \quad 72_{1}^{\circ} \mathrm{E} \quad 74_{1}^{\circ} \mathrm{E}$
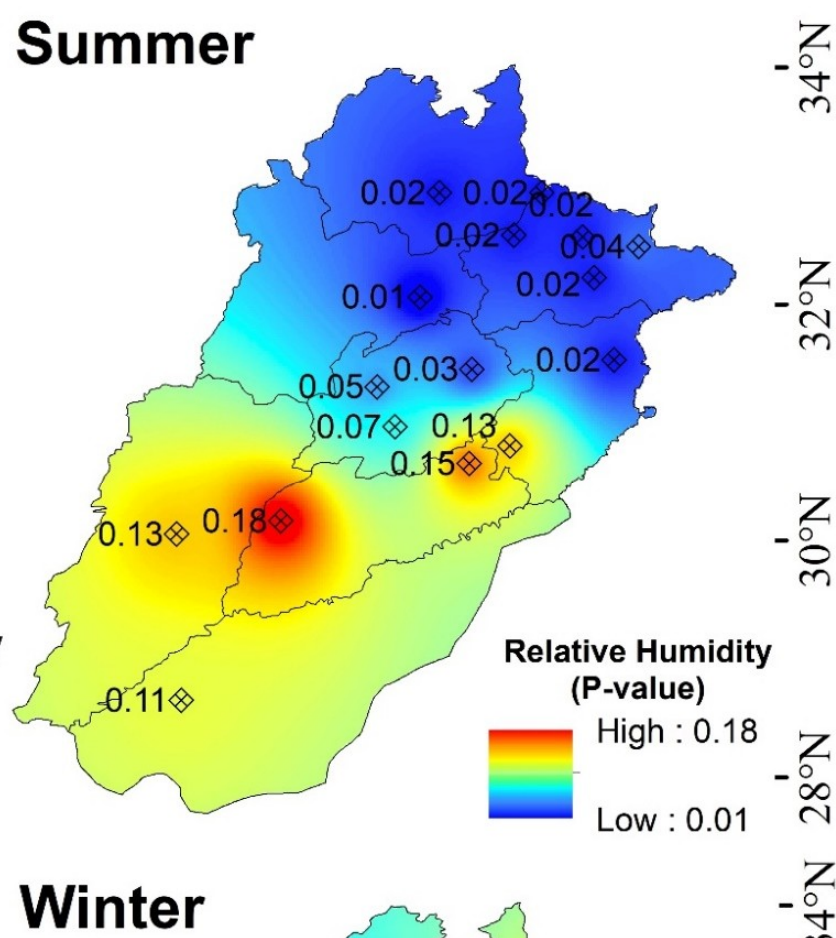

Winter $-\frac{m}{\mathrm{~m}}$

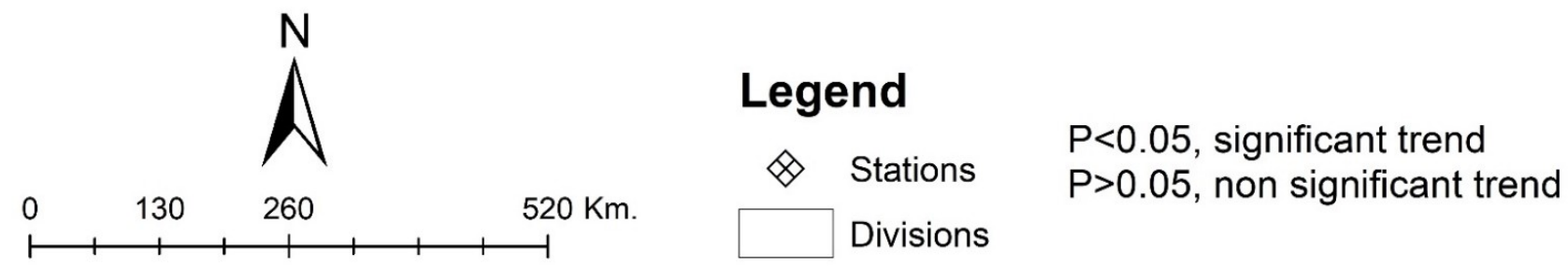

Figure 7. Seasonal $p$-values and the trends in relative humidity of the 16 stations of Punjab, Pakistan, over the period 1979-2014. 

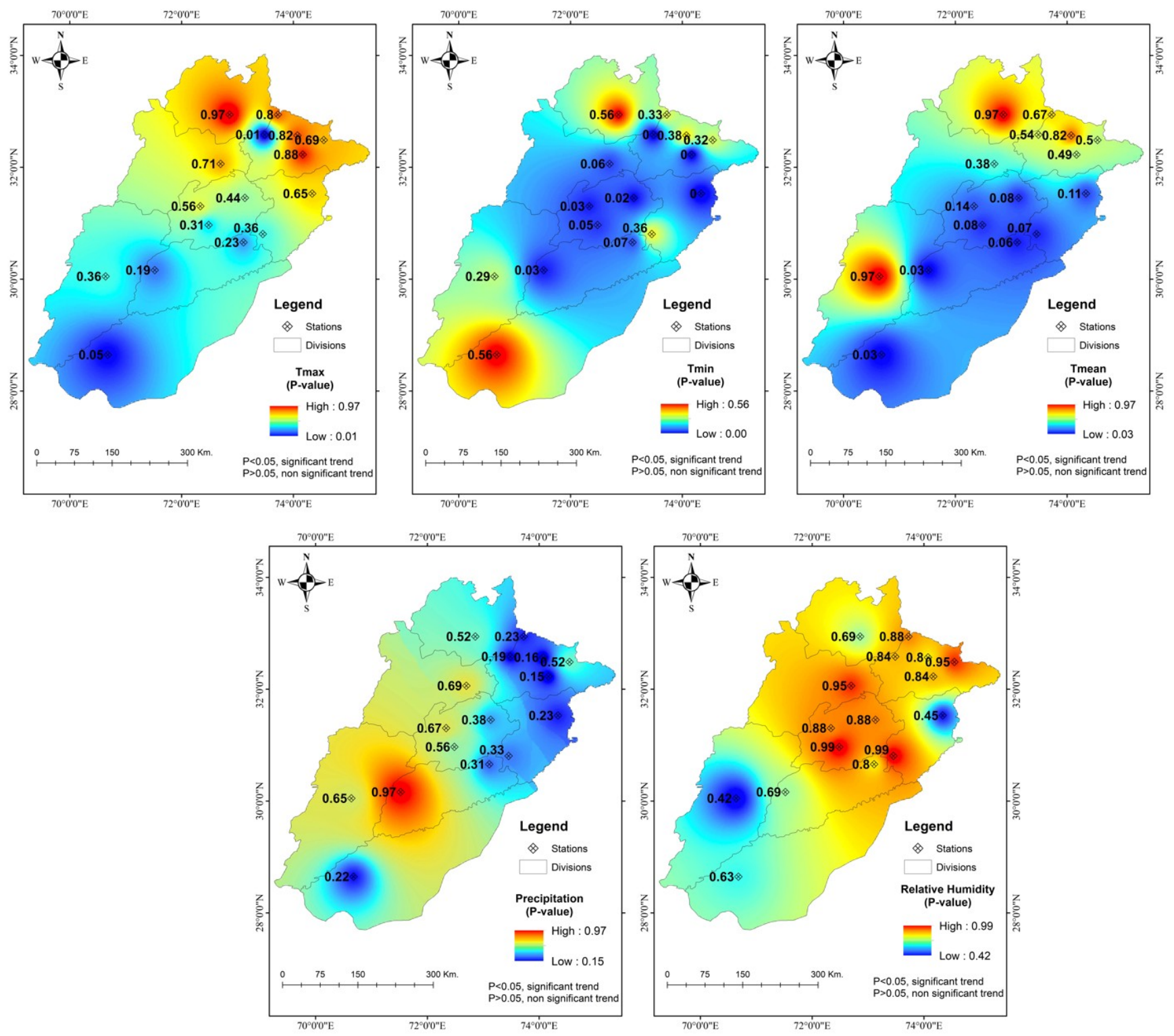

Figure 8. Annual temporal trends and $p$-values for $\mathrm{T}_{\max }\left({ }^{\circ} \mathrm{C}\right), \mathrm{T}_{\min }\left({ }^{\circ} \mathrm{C}\right), \mathrm{T}_{\operatorname{mean}}\left({ }^{\circ} \mathrm{C}\right)$, precipitation $(\mathrm{mm})$, and relative humidity at the 16 stations of Punjab, Pakistan, over the period 1979-2014.

\section{Discussion}

Particularly now, the severe hazards that present high risks to humans and the ecosystems are extreme climatic patterns [77]. Hence, with evidence showing that the severity of extreme climatic patterns has increased since the 1990s, these events are under serious consideration and gaining attention. As part of a time series analysis, the recognition of a monotonic trend has prime importance. For applying statistical methods, a speculative composition requires the detection of trends. Due to the repercussions of climate variability, the non-homogeneity in the trends of hydrological series was shown. Statistical tests assist in identifying trends in stochastic or non-random arrangements. Understanding their potential or size permits us to make an accurate decision regarding already present trends [78]. The data was analyzed through various procedures, which involved performing tests to detect trends, occurrences, and stationarity of the data for the whole Punjab region, the results of which are shown in Table 4 . The main concern during trend detection is finding out whether the values of a time series dataset have a familiar fluctuation with the increase of time; to this end, the ADF test aims to evaluate whether the average values 
or variances of a series change with the time. Almost all analysis techniques must suppose amorphous stationarity in the datasets whether the methods are linear or not. Hence, it is compulsory to check the stationarity using some standard and finite modules. At the same time, the examination of non-stationarity may lead to some awareness of the actual physical implementations.

Consequently, checking whether the datasets are stationary has supreme importance [56]. The result of the stationarity test is given in Table 4. Every single series appeared to be significantly stationary after using the unit root hypothesis of the ADF test. After passing the datasets through the SS, MK, and CS tests, we observed that the power of the CS test was lower in comparison with the MK test for the trends distribution; therefore, the final decision was made based upon the MK test results, which is in line with Rutkowska et al. [78].

The analysis of contemporary past climate data of these stations showed a large variation in precipitation and temperature [8]. $\mathrm{T}_{\min }$ presented a significant $(p<0.05)$ trend, while $T_{\text {mean }}$ presented a non-significant $(p>0.05)$ trend in spring (MAM). Precipitation manifested a non-significant $(p>0.05)$ trend in summer (JJA) but a significant $(p<0.05)$ trend in autumn. Further, the relative humidity showed a non-significant $(p>0.05)$ trend in the seasonal and annual data. Nonetheless, at the annual scale, no trend was revealed by any of the variables for Punjab, Pakistan.

\subsection{Absolute Changes and Trends of Temperature Indices}

Punjab, Pakistan, is classified into two regions: (1) southern Punjab, which is an arid region with comparatively high temperatures in the range of $18.5-31.4{ }^{\circ} \mathrm{C}$ and a harsh climate, and (2) central Punjab, which is a semi-arid region with a mean temperature in the range of $10.5-24.4{ }^{\circ} \mathrm{C}$ and a mild climate $[9,79]$. Usually, we assume that the main threat of climate variability is to the agriculture of all regions, including arid, semi-arid, and warmer areas worldwide $[9,80]$. During the past three decades, the increasing temperature was the most crucial factor causing unsustainability [81,82].

In central and southern Punjab, Pakistan, the intensity of severe maximum temperature indices during 1965-2009 was spotted [83,84]. According to [73], during 1997-2002, the highest significant quick variability in the linear trends of temperature was detected for most areas in the Punjab region; as Rahman and Dawood [27] stated, temperature imbalance is the reason for the drought. The country went through a previous and deep-rooted drought during this period, ultimately harming sustainability.

\subsection{1. $\mathrm{T}_{\max }$}

MK and SS trend tests were used to identify patterns during the study of annual and seasonal temperature variability to determine whether the patterns were increasing, decreasing, or remained unchanged. Depending on the $p$-value, the null hypothesis of the MK test for trends was accepted or rejected. As per the test results, some of the stations showed no or a low $\mathrm{T}_{\max }$ trend over the period 1979-2014. The summer season was rainy and hot. In contrast, the winter was dry and cold [85]. On a seasonal basis, the Khanpur station during spring and the Khanpur, Multan, Okara, and Sahiwal stations during winter displayed significant $(p<0.05)$ trends during the period 1979-2014 (Tables 5 and 6). Our findings coincide with the results of Abid et al. [44] in which Khanpur station showed a significant trend in summer (JJA) and winter (DJF) temperature and precipitation during 1980-2013. The annual significant $(p<0.05)$ trend was only observed by MB Din station for $T_{\max }$.

Hence, a non-significant $(p>0.05)$ annual trend was noticed in Chakwal, DG Khan, Faisalabad, Gujranwala, Gujrat, Jhang, Jhelum, Khanpur, Multan, Okara, Sahiwal, Sialkot, TT Singh, and Sargodha. For the summer season, the temperature of Jhelum was extreme [44]. Similarly, in Gujrat and TT Singh, severe $T_{\max }$ and $T_{\min }$ present significant climate-related risks to sustainability, where past trends show a seasonal increase in temperatures. Multan station is in the arid and hottest region of Punjab, with cold winters and sweltering summers. The summer season lasts from May till September, while the winter 
season starts in December and remains till February. The lowest average temperature in the winter (DJF) season was $4.5^{\circ} \mathrm{C}$, and the highest mean temperature in June was $42.3^{\circ} \mathrm{C}$. On 27 May 2010, a record-breaking temperature of $50{ }^{\circ} \mathrm{C}$ was recorded [86]. In response to such weather conditions, variations in summer (MAM) and winter (DJF) seasons swiftly occurred. A non-significant $(p>0.05)$ trend was shown in the summer season by all stations during 1979-2014. Hussain et al. [87] explained that, in summers, 91\% of the farmers stated that the day temperatures were higher than the previous years of this decade; as many as $62.3 \%$ reported the same thing for summer nights. Around $36 \%$ of farmers said that they found summer nights less hot than days. However, none of the stations showed a significant $(p<0.05)$ trend in the summer and autumn seasons regarding $\mathrm{T}_{\max }$.

Further, almost $54.2 \%$ of them believed that there were more cool days in the winter season, and $42.9 \%$ stated the opposite. On the other hand, $19 \%$ of the farmers said they found winter days colder than nights, while $79 \%$ of respondents noticed less cool days than nights in the winter season. However, few of them observed no change in the past ten years in the winter and summer seasons. Even so, most of the farmers believed that they experienced an instantaneous variability in the climate, which highly affected the agriculture patterns and ultimately lead to the changing sustainability.

\subsection{2. $\mathrm{T}_{\min }$}

Overall, strengthening the previous studies $[73,88], \mathrm{T}_{\min }$ in the spring season showed a significant $(p<0.05)$ trend. By showing no trend in the summer season, $\mathrm{T}_{\min }$ went against [89], where an increasing trend was reported in many areas of Pakistan. According to the MK and SS tests used in the trend analysis for minimum temperature $\left(\mathrm{T}_{\min }\right)$, Faisalabad, Gujranwala, Jhang, Lahore, MB Din, and Multan, had highly significant $(p<0.05)$ annual trends. Our results contrast with the findings of Abid et al. [44], who stated that the temperature of Faisalabad station presented significant $(p<0.05)$ trends in summer (JJA) and winter (DJF) during 1980-2013. We found a non-significant $(p>0.05)$ trend in Faisalabad for these seasons.

There was no evident trend for summer at any of the stations during 1979-2014. Further, a significant $(p<0.05)$ trend was shown for autumn in Chakwal, Faisalabad, Gujranwala, Jhang, Lahore, MB Din, Sahiwal, Sargodha, and TT Singh. In winter, only Lahore and Okara manifested significant $(p<0.05) \mathrm{T}_{\min }$ trends.

\subsection{3. $\mathrm{T}_{\text {mean }}$}

$\mathrm{T}_{\text {mean }}$ is the difference between $\mathrm{T}_{\max }$ and $\mathrm{T}_{\text {min }}$; it shows how the trends influence each other, either similarly or oppositely. From 1951 to 2000, remarkable variations in $\mathrm{T}_{\text {mean }}$ and its frequency in Punjab, Pakistan, were observed [83,84]. According to the predictions of many global circulation models (GCMs) compared with historical measurements, warming will be enhanced in Punjab in the future $[8,42]$. By the end of this century, an approximately $2-4{ }^{\circ} \mathrm{C}$ increase in the $\mathrm{T}_{\text {mean }}$ of Punjab is predicted $[28,90]$. In the current study, by using the MK and SS tests, the most significant trends were found in the Multan region. Highly significant annual, spring, autumn, and winter trends were found over the period, but no trend was found for summer. Some of the stations, namely, Chakwal, DG Khan, Faisalabad, Gujranwala, Gujrat, Jhelum, MB Din, Sargodha, Sialkot, and TT Singh, did not show any significant trend, annually or seasonally. The remaining stations experiences slight trends over the duration. The annual and spring measurements of the Khanpur and Multan stations showed a significant $(p<0.05)$ trend for Tmean. Jhang and Multan in autumn and Lahore, Multan, Okara, and Sahiwal in winter displayed significant $(p<0.05)$ trends. The increase in temperature of $2-3{ }^{\circ} \mathrm{C}$ in Gujrat, Sialkot, Jhelum, Gujranwala, and Chakwal showed a clear demonstration of warming in the climate [8,91].

\subsection{Absolute Changes and Trends in Precipitation}

The annual results and trends in precipitation of Punjab, Pakistan, are shown in Figure 8. Within a $95 \%$ confidence interval, the SS and MK test results specified vari- 
ability in the trends in precipitation on annual and seasonal timescales during 1979-2014. As discussed earlier, no trends were found for annual precipitation in Punjab, Pakistan, using any method, which contradicted the study of [41], who reported a decreasing trend in annual precipitation in this region. Regarding station-specific data, a highly significant $(p<0.05)$ trend in all four seasons was detected in the Chakwal station, as shown in Figure 6. Other than that, some of the stations, namely, DG Khan, Faisalabad, Jhang, Khanpur, Multan, Okara, Sahiwal, Sargodha, and TT Singh, did not show any seasonal or annual significant trends over the period.

Gujrat presented a significant $(p<0.05)$ trend for winter (DJF) and summer (JJA), which agreed with the findings of [37], who demonstrated a declining tendency in precipitation in several locations of Pakistan. Gujrat is a partially rain-fed region and mostly relies on precipitation and resources from groundwater for the production of agriculture. Its climate is modest. The mean annual precipitation ranges from 697 to $1401 \mathrm{~mm}$. The main crops of this area are sugarcane, rice, and wheat. The past trends show a tremendous decrease in the precipitation in Gujrat, due to which, the agriculture productivity was highly affected and still under a significant risk [43,92]. The study of Abid et al. [44] stated that, during 1980-2013, Jhelum station experienced a decreasing trend in summer (JJA) precipitation, while Faisalabad showed a decreasing trend in winter (DJF) precipitation. These results are the same as the results of the current study, which showed a non-significant $(p>0.05)$ trend in these seasons regarding precipitation in Faisalabad.

The basis of risk mapping is the variability in precipitation patterns, and it has an essential role in climate change monitoring [69]. Northern Punjab has average precipitation between 300 and $600 \mathrm{~mm}$, and southern Punjab has average precipitation between 75 and $200 \mathrm{~mm}[9,79]$. The summer weather is hot and somewhat rainy, while the winter season is dry and cold. Because of the monsoons' influence on climatic events, $60-65 \%$ of precipitation is concentrated from May to September [85]. This type of behavior was due to extreme precipitation patterns and indicates that uneven atmospheric events are a reason for the climate variability over the past few years [93].

Usually, northern Punjab has a high precipitation ratio, which decreases when moving toward southern Punjab. The spatial dispersion of cloud cover is the reason for variations in the precipitation across Punjab, Pakistan. The cloud cover is thicker in the north compared with the south. Due to dense precipitation, the north is cooler than the south. The covering of clouds is more extensive, in monsoon and post-monsoon seasons, which sometimes leads to heavy precipitation in the winter season in the north of Punjab, Pakistan. There is more precipitation in the eastern part of Punjab compared to the west.

Precipitation patterns were affected by the elevation above mean sea level. Because of its northern location and subhumid climate, as well as carrying low amounts of precipitation and having high temperatures, Rawalpindi received more precipitation than the other cities. Multan, like the other cities in the study region, received less precipitation due to its southern location and arid climate. In agreement with [41], we found that for Multan, Bahawalnagar, Faisalabad, Sargodha, and Rawalpindi, the wettest years were 2010, 1992, 1997, 2005, and 2007, whereas the driest years were 2002, 1985, 1999, 1987, and 2002. The year 1999 was the driest year, mainly because of no precipitation during autumn in the southern region of Punjab. Along with this, the spring season of 2000 observed no precipitation. This leads to the conclusion that there was no temporal trend in precipitation, but spatial patterns were evident regarding the mean annual precipitation under the impact of elevation above the mean sea level. Same as the study of [73], our findings also found that the majority of the winter precipitation was driven by western disturbances, which resulted in decreased precipitation at most sites in the study region.

\subsection{Annual and Seasonal Trends in Relative Humidity}

For determining the distribution and occurrence of clouds, an important factor is relative humidity [94]. Patterns of relative humidity are related to the roles of the other analyzed climatic variables. Relative humidity has a direct relation with precipitation but 
an inverse relation with temperature. A decrease in precipitation also causes a reduction in the relative humidity and the temperature will increase [95]. Changes in relative humidity in the atmosphere are very impactful if the atmospheric relative humidity is interconnected to the precipitation and the surface energy exchanges. To realize the current variability in climate and the prediction for future climate changes, the changes in relative humidity and the assessment of moisture amounts are necessary for estimating the availability of water content and precipitation rate in the atmosphere [96].

In light of Kousari and Zarch's [97] research results, during recent years, a significant decrease in average yearly relative humidity and a close connection between relative humidity and air temperature were found. We also identified a similar decreasing trend in relative humidity, specifically in the summer season. Other than that, no significant trend was found, seasonally or annually, over Punjab within the timescale 1979-2014. The MK test also showed the same Tau values but in the opposite direction for the maximum temperature and relative humidity in the summer (Table 6). No significant trend was found either annually or for spring or autumn regarding relative humidity, as represented in Figure 7. However, in the summer season, some stations, namely, Chakwal, Faisalabad, Gujranwala, Gujrat, Jhang, Lahore, MB Din, Sargodha, and Sialkot, presented significant $(p<0.05)$ trends for relative humidity. In winter, DG Khan, Sahiwal, Sargodha, and TT Singh showed significant $(p<0.05)$ trends.

Contrarily, Khanpur, Multan, and Okara presented non-significant $(p>0.05)$ trends, both annually and seasonally. All the stations presented non-significant $(p>0.05)$ trends in spring and autumn regarding relative humidity (Figure 7). A decreasing trend in humidity has a negative influence on the environment [98]. Figure 8 provides the explanation of the station-specific annual time series and the trends for all studied variables for Punjab, Pakistan, during 1979-2014.

Figure 9a shows the average of the $850 \mathrm{hPa}$ geopotential height (HGT) of the study area during 1979-2014. The figure indicates that, generally, there were two areas with high and low pressure affecting the climate of Punjab. The two areas were (1) the Tibetan high pressure (THP) that was located on the Tibet plateau and (2) a low pressure that was located in the Bay of Bengal (BBLP) to the southeast of Iran. Changes in these two pressure centers were responsible for all climatic phenomena in the study area. Further, there were two centers for each of the two mentioned pressure patterns: the western center of the THP located in northern Punjab and the other western center of BBLP located in the study area. The result of separately studying the dry and wet periods based on seasonal precipitation of each station ( $\leq \pm 2$ std for precipitation) during 1979-2014 showed that there were two periods 1999-2002 and 2011-2014 that were found to be very dry and very wet years, respectively, in the study area (Figure 9a). A wet/dry period was defined as having at least 50 percent of the studied stations (i.e., at least eight stations) experiencing higher/lower than average precipitation. This situation continued for at least three seasons.

The changes in the HGT patterns for these two periods showed that a dry period (1999-2002) happened when there was a higher than usual HGT for the western center of THP and a lower than normal HGT for the eastern center of the THP. In this situation, the strengthened western center of the THP extended southward and covered the study area. Because of the high-pressure systems that make a stable climate condition, stopping air mass from ascending, they result in a clear sky $[99,100]$; therefore, this produces a condition with higher-than-normal temperature and lower-than-normal precipitation and humidity (Figure 9b). A wet period (2011-2014) happened when there was a higherthan-normal HGT for the eastern center of the THP and a lower-than-normal HGT for the western center of the THP. In this situation, the weakened western center of the THP shrunk northward and did not cover the study area; as such, the study area was affected by low pressure and, because of the nature of low-pressure systems, this produced an unstable climate condition, letting air mass ascend, and resulting in a cloudy sky [97]. This produced conditions with lower-than-normal temperature and higher-than-normal precipitation and humidity (Figure 9c). 

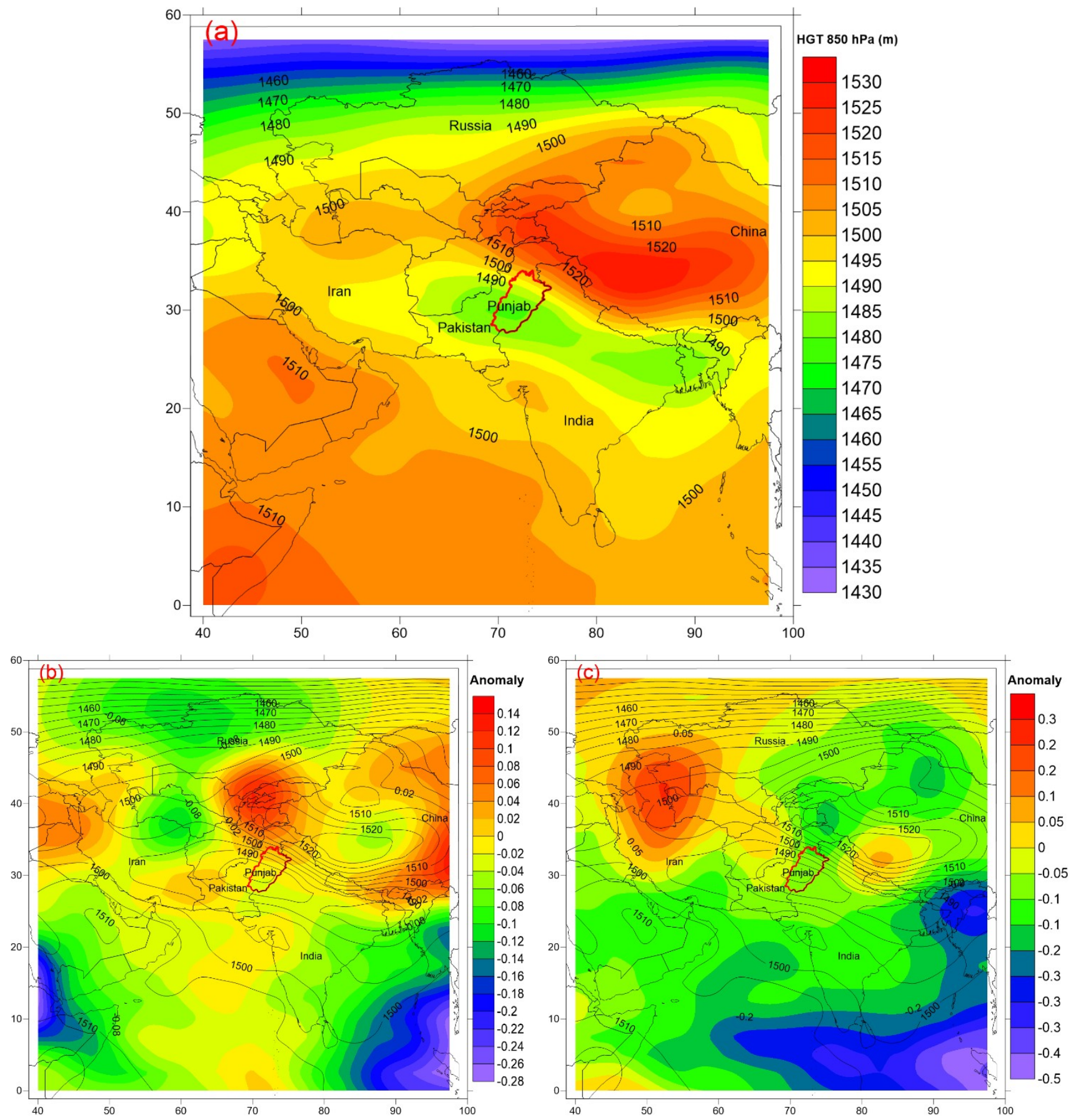

Figure 9. Average of the $850 \mathrm{hPa}$ HGT during different periods in Punjab, Pakistan: (a) average of the 850 hPa HGT during 1979-2014, (b) average of the 850 hPa HGT during 1979-2014 (contour) and the anomaly of the 850 hPa HGT for the dry period (1999-2003) (shaded), and (c) average of the $850 \mathrm{hPa}$ HGT during 1979-2014 (contour) and the anomaly of the $850 \mathrm{hPa}$ HGT for the wet period (2011-2014) (shaded).

Figure 10 shows the anomaly of the 850 hPa HGT during 1979-2014. The figure indicates that both centers of the THP and BBLP were weaker during the study period. Therefore, it seems that despite having a weaker THP, especially in its western center, because of a weaker THP in the eastern part, the BBLP could move to a higher latitude, and it could have a negative impact on precipitation in Punjab in the future. This situation can have the same impact on all the areas located between 20 and $30^{\circ} \mathrm{N}$ from India to Pakistan, Afghanistan, and southeastern Iran (Figure 10). 


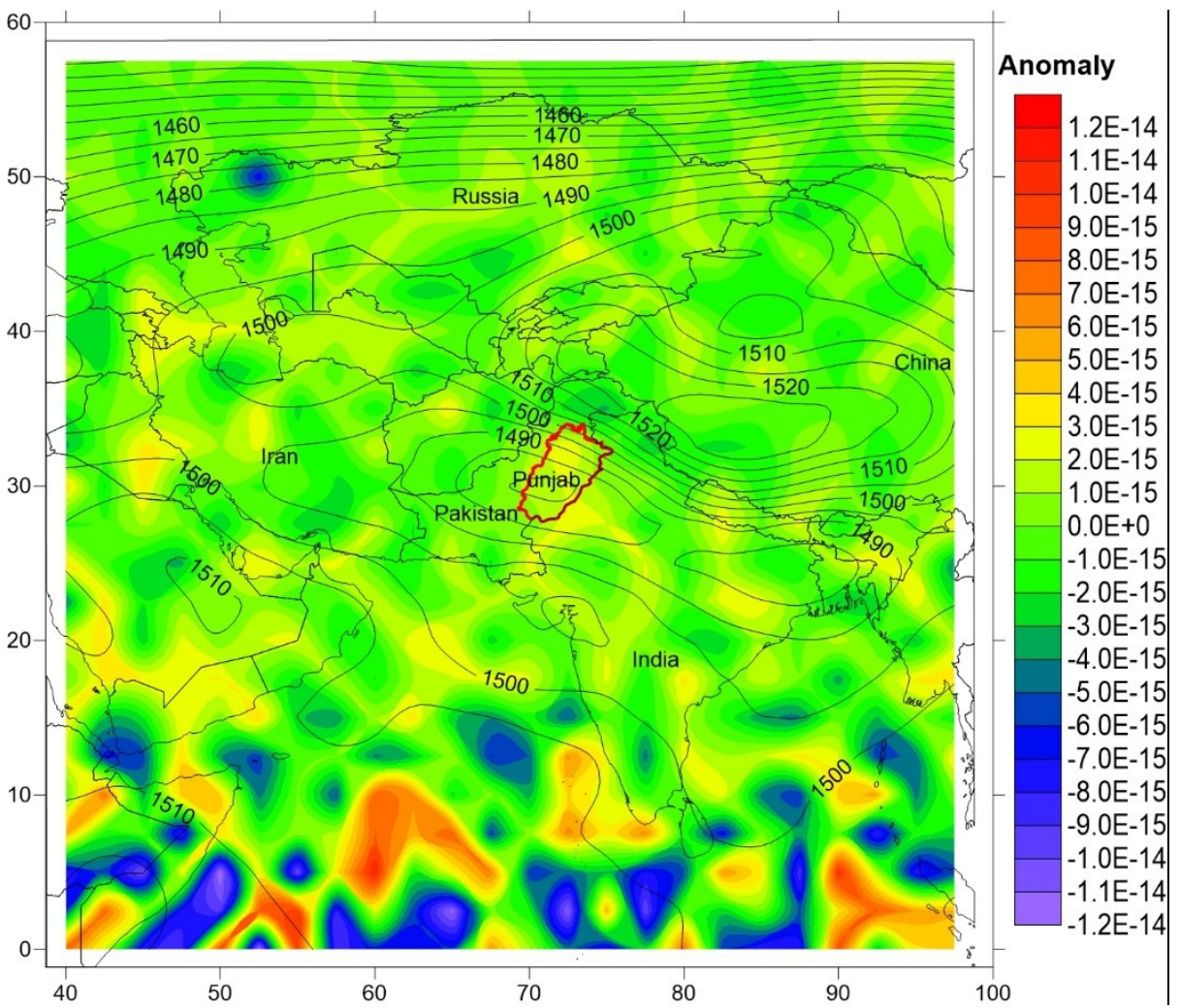

Figure 10. The anomaly of the $850 \mathrm{hPa}$ HGT (shaded) and the mean of the $850 \mathrm{hPa}$ HGT (contour) during 1979-2014.

\subsection{Comparison of Trends}

Further studies [101,102] described a review of the increasing water shortages in arid (e.g., MB Din) and semi-arid regions (mostly TT Singh) because of the increasing risks related to climate variability. Only a few researchers have identified positive changes in the precipitation and temperature in Punjab, Pakistan [103]. According to all methods (Tables 5 and 6 ), there were no significant trends in the annual $\left(T_{\max }, T_{\min }, T_{\text {mean }}\right.$, precipitation, and relative humidity) time series for Punjab province over the period 1979-2014. Referring to the MK test (Table 6), extremely significant $(p<0.05)$ trends were noticed for $\mathrm{T}_{\min }$ in spring and autumn and for precipitation in autumn. Within a $95 \%$ confidence level, the SS results were very similar to the MK results. In the station-specific analyses, the results for two vulnerable stations are presented in Tables 7 and 8. MB Din displayed a highly significant $(p<0.05)$ trend and TT Singh displayed the most non-significant $(p>0.05)$ trend. Just like the results of Shirazi et al. [104], we found a significant $(p<0.05)$ trend in the summer and autumn precipitation in MB Din. Relative humidity at this station showed a significant $(p<0.05)$ trend in summer. Annually significant $(p<0.05)$ trends were observed for $\mathrm{T}_{\max }$ and $\mathrm{T}_{\min }$ at this station. $\mathrm{T}_{\text {mean }}$ presented non-significant $(p>0.05)$ trends, both annually and seasonally.

All the stations have been discussed appropriately, but a highly significant trend at $\alpha=0.05$ was revealed by MB Din and TT Singh, which show them to be the most vulnerable, as is evident in Tables 7 and 8. MB Din is situated in central Punjab, Pakistan; therefore, it is likely to show fluctuations in climate. TT Singh is situated in a mixed cropping zone, it covers $3252 \mathrm{~km}^{2}$, and it is in the major irrigated zone. There are extreme hot (in summer (JJA)) and cold (in winter (DJF)) climate events that occur in these areas [43]. In TT Singh, the seasonal precipitation showed a historical decreasing trend [44]. 
Table 7. MK test results for MB Din for the period 1979-2014.

\begin{tabular}{|c|c|c|c|c|c|}
\hline Variable & Period & Z Statistic & $p$-Value & Tau & Sen's Slope \\
\hline \multirow{5}{*}{ Precipitation } & Annual & 1.3212 & 0.1864 & 0.155556 & 5.990059 \\
\hline & Spring & -1.7843 & 0.07437 & -0.20952 & -1.986163 \\
\hline & Summer & 2.4381 & 0.01476 * & 0.285714 & 6.888515 \\
\hline & Autumn & 2.3703 & $0.01778 *$ & 0.277999 & 2.180419 \\
\hline & Winter & -0.93984 & 0.3473 & -0.11111 & -1.119856 \\
\hline \multirow{5}{*}{ Relative Humidity } & Annual & 0.20431 & 0.8381 & 0.0254 & 0.000248441 \\
\hline & Spring & -0.83087 & 0.406 & -0.09841 & -0.001344464 \\
\hline & Summer & 2.2474 & $0.02461 *$ & 0.263492 & 0.00381155 \\
\hline & Autumn & 1.3895 & 0.1647 & 0.163622 & 0.002674025 \\
\hline & Winter & -1.7299 & 0.08366 & -0.20317 & -0.002960556 \\
\hline \multirow{5}{*}{$\mathrm{T}_{\max }$} & Annual & 0.013621 & $0.013621 *$ & 0.00317 & 0.001644908 \\
\hline & Spring & 1.1305 & 0.2583 & 0.133333 & 0.0560698 \\
\hline & Summer & -1.5664 & 0.1173 & -0.18413 & -0.05785319 \\
\hline & Autumn & -0.87182 & 0.3833 & -0.10326 & -0.03230826 \\
\hline & Winter & 0.77639 & 0.4375 & 0.0921 & 0.01847129 \\
\hline \multirow{5}{*}{$\mathrm{T}_{\min }$} & Annual & 3.6368 & $0.000276^{*}$ & 0.425397 & 0.02845178 \\
\hline & Spring & 2.8195 & 0.004809 * & 0.330159 & 0.0377603 \\
\hline & Summer & 0.12259 & 0.9024 & 0.0159 & 0.001404296 \\
\hline & Autumn & 3.8142 & 0.000137 * & 0.446386 & 0.06058493 \\
\hline & Winter & 1.7843 & 0.07437 & 0.209524 & 0.02160051 \\
\hline \multirow{5}{*}{$\mathrm{T}_{\text {mean }}$} & Annual & 0.61294 & 0.5399 & 0.0730 & 0.008112258 \\
\hline & Spring & 1.6754 & 0.09386 & 0.196825 & 0.04790999 \\
\hline & Summer & -1.0761 & 0.2819 & -0.12698 & -0.02465581 \\
\hline & Autumn & 0.62662 & 0.5309 & 0.0747 & 0.006903813 \\
\hline & Winter & 1.294 & 0.1957 & 0.152381 & 0.01773802 \\
\hline
\end{tabular}

(The asterisk "*" sign represents the presence of a significant trend in the datasets).

Table 8. MK test results for TT Singh for the period 1979-2014.

\begin{tabular}{|c|c|c|c|c|c|}
\hline Variable & Period & Z Statistic & $p$-Value & Tau & Sen's Slope \\
\hline \multirow{5}{*}{ Precipitation } & Annual & 0.5857 & 0.5581 & 0.0698 & 0.7988654 \\
\hline & Spring & -0.55846 & 0.5765 & -0.06667 & -0.2135985 \\
\hline & Summer & 1.5664 & 0.1173 & 0.184127 & 1.015149 \\
\hline & Autumn & 0.36776 & 0.713 & 0.0444 & 0.06515984 \\
\hline & Winter & -0.12259 & 0.9024 & -0.01587 & -0.01869019 \\
\hline \multirow{5}{*}{ Relative Humidity } & Annual & -0.013621 & 0.9891 & -0.00317 & $-7.18 \times 10^{-6}$ \\
\hline & Spring & -0.61294 & 0.5399 & -0.07302 & -0.000677379 \\
\hline & Summer & 1.7843 & 0.07437 & 0.209524 & 0.001419451 \\
\hline & Autumn & 1.6209 & 0.105 & 0.190476 & 0.001695443 \\
\hline & Winter & -2.084 & 0.03716 * & -0.24444 & -0.001665935 \\
\hline \multirow{5}{*}{$\mathrm{T}_{\max }$} & Annual & 1.0216 & 0.307 & 0.120635 & 0.01315947 \\
\hline & Spring & 1.6754 & 0.09386 & 0.196825 & 0.05313781 \\
\hline & Summer & -1.1033 & 0.2699 & -0.13016 & -0.01940146 \\
\hline & Autumn & 0.068104 & 0.9457 & 0.00952 & 0.002871189 \\
\hline & Winter & 1.7843 & 0.07437 & 0.209524 & 0.03589588 \\
\hline \multirow{5}{*}{$\mathrm{T}_{\min }$} & Annual & 1.975 & 0.04826 * & 0.231746 & 0.01252046 \\
\hline & Spring & 1.9205 & 0.05479 & 0.225397 & 0.02922167 \\
\hline & Summer & -0.5857 & 0.5581 & -0.06984 & -0.00636988 \\
\hline & Autumn & 2.084 & 0.03716 * & 0.244444 & 0.02800059 \\
\hline & Winter & 0.55846 & 0.5765 & 0.0667 & 0.004580776 \\
\hline \multirow{5}{*}{$\mathrm{T}_{\text {mean }}$} & Annual & 1.7299 & 0.08366 & 0.203175 & 0.01432999 \\
\hline & Spring & 1.8388 & 0.06594 & 0.215873 & 0.03954732 \\
\hline & Summer & -1.2395 & 0.2152 & -0.14603 & -0.01469914 \\
\hline & Autumn & 1.2395 & 0.2152 & 0.146032 & 0.0121481 \\
\hline & Winter & 1.5664 & 0.1173 & 0.184127 & 0.02027609 \\
\hline
\end{tabular}

(The asterisk "*" sign represents the presence of a significant trend in the datasets).

However, if we describe each zone individually, there are notable differences. In MB Din, $\mathrm{T}_{\max }$ showed a significant annual trend. Regarding the seasonal evaluation, relative humidity in winter (DJF) showed a significant $(p<0.05)$ trend. The annual and autumn $\mathrm{T}_{\min }$ showed a significant $(p<0.05)$ trend. We discerned a fluctuating pattern in the precipi- 
tation in some years, for example, autumn of 1999 and spring of 2000 were dry seasons with zero precipitation in TT Singh. $\mathrm{T}_{\max }$ and $\mathrm{T}_{\text {mean }}$ showed non-significant $(p<0.05)$ trends at this station.

\section{Climate Variability and Sustainability}

Sustainability is a major area of interest in both developed and developing countries, but the recent threat to sustainability can be substantially more critical in developing countries (Pakistan) than they are in developed countries. The main parameters are temperature and precipitation. This research aimed to weigh up current and future climate change and related challenges in Punjab, Pakistan, by considering proposed solutions for sustainability. Despite recognizing the specific variables that can cause the changes in climate across Punjab, Pakistan, our aim was not only to identify the critical indicators that capture climatic instability but also to suggest measures to build a sustainable environment. In this regard, the aim was to directly take part in the efforts that help build a sustainable environment for Punjab, Pakistan. According to the trends, the changes in variables will result in impacts that will contribute negatively to sustainability. The current variability in climate directly negatively affects sustainability and thus also influences the upcoming scenarios. Previous studies described that sustainability indicators were affected by historical climate conditions [105]. MacDonald [106] claimed that higher temperatures, earlier spring warming, and decreased precipitation contributed to the increased environmental imbalance, unsustainability, and drought. Our study contributed the same way. We found precipitation variability and a rise in temperature in the Punjab region. A recent study by Ali et al. [107] found that the main Punjab regions (Bahawalpur, Faisalabad, Mianwali, Multan, Sargodha, and Rahim Yar Khan) were affected by extreme flooding and drought events. Due to warming and the above-explained scenarios, Punjab is facing an alarming situation regarding sustainability. The Punjab region, especially Lahore, is going through the deadliest smog cover in the winter season for the past 5 years.

One of the climate change consequences is drought. At the same time, this occurs gradually over a relatively long period; it affects not only agriculture $[108,109]$ and water resources but also the social and economic sectors. This natural event occurs in almost all climatic regions, although its characteristics fluctuate. The main consequences of climate change, which is caused by increasing greenhouse gas concentrations (especially carbon dioxide) in the atmosphere, are changes in various factors ranging from global temperature, solar radiation absorption, precipitation characteristics, humidity, wind speed, runoff, and sea level to water resources, energy, wildlife, and ecosystems $[93,110]$. The direct connection between climate change and sustainability was stated in the current research. It will possibly assist the upcoming new ideas and allow for farmers to intensify their systems and techniques, both individually and collectively, toward changing the environment and adaptability consistently regarding all aspects of sustainability.

Urbanization has been increasing in Punjab province for the past few decades. Because it is richer in industrialization than other provinces and has many educational and employment opportunities [111], the people prefer to move to Punjab. The rate of urbanization in Punjab is 36.71 percent [112]. According to the 2017 census, Pakistan's total population is 207.77 million and the distribution is as follows: 30.52 million in Khyber Pakhtunkhwa (KPK), 5 million in Federally Administered Tribal Area (FATA), 47.89 million in Sindh, 12.34 million in Baluchistan, and 2 million in Islamabad. A major portion of the population that accounts for 110.01 million people is in Punjab province, which is approximately 52.95 percent of Pakistan's population [1]. This swiftly growing population; the lack of a productive and arranged public transport system, resources, and facilities; and the rapidly increasing rate of personally owned vehicles have an inauspicious effect on the sustainable environment of Punjab. According to the Punjab Development Statistics, 2017, there are 16907529 registered motor vehicles in Punjab, where 79.39 percent are privately owned motorbikes and scooters, and 11.58 percent are personal cars [106]. The prime method of urban transportation of this province is via cars, motorbikes, particularized 
buses, vans, and qingqi. All of these collectively are substantially affecting the sustainability and climate of Punjab through producing a large volume of smoke through the combustion of fossil fuels [113]. According to a study by Stroik et al. [114], without taking into account natural disasters, anthropogenic emissions accounted for more than half of the average global surface temperature rise between 1951 and 2010. As per EDGAR statistics [115], there was a $169 \%$ increase in emissions created by industrial operations, from 17,098 to $46,122 \mathrm{Gg}$. Most of the $\mathrm{CO}_{2}$ is produced by industrial processes and procedures, widespread vehicle use, and power generation, whereas methane $\left(\mathrm{CH}_{4}\right)$ is produced by poor waste management, conventional agricultural operations, and fossil fuel combustion [116]. Hussain et al. [117] explained how industrialization and urbanization increased the temperature by increasing GHG emissions and accounts for up to $80 \%$ of the $\mathrm{CO}_{2}$ production in Punjab, Pakistan. Defending the work of [118-120], alteration in land use patterns caused by anthropogenic operations increase $\mathrm{CO}_{2}$ emissions to the atmosphere, causing temperatures to rise. The study of [119] demonstrated that variations in land use events, vegetation cover, and deforestation were the principal causes of climate change. Consequently, air pollution is rising expeditiously in Punjab and is documented to be on 195.71 million tons of carbon dioxide $\left(\mathrm{CO}_{2}\right)$ emissions annually, which is affecting human health and the sustainable environment [121].

The reported 3590 different kinds of industries in Punjab, Pakistan, also contributing a great part in polluting the environment. In the study of Ghous et al. [122], in the period from 1981 to 2013, a change in temperature due to the increasing pollution in Punjab was found to be $0.021^{\circ} \mathrm{C}$ /year. Furthermore, precipitation decreased at an average rate of $0.09 \mathrm{~mm} /$ year. Their findings declared that the anthropogenic activities influenced the climate of Lahore, a city of Punjab. Moreover, they revealed that this change will lead to altering the future climate too, which we have explained in our study. Van de Vliert et al. [123] illustrated the mean temperature showed an increasing trend during the period 1961-2010 in all districts of Punjab, Pakistan. However, in this study, the most significant trends were shown by the Multan station during 1979-2014. Due to this fluctuation in temperature, the climate changed quickly, and drastic climate patterns happened more regularly during these years in Punjab, Pakistan. This higher temperature is becoming the cause of extreme events, such as floods and droughts [123]. As the global temperature has been rising over the recent decade and has increased the effects of climate change [124], the Earth's atmosphere has reached a threshold value, resulting in a combination of moderate and smooth climate change, such as rapid cooling, drying, and warming. Moreover, deforestation is reducing transpiration, which leads to less cloud formation, less rainfall, and enhanced dryness [120]. Correspondingly, anthropogenic activities became a significant contributor to droughts and floods [125].

\section{Conclusions}

The current study inspected the spatio-temporal heterogeneity of temperature parameters, namely, temperature $\left(\mathrm{T}_{\max }, \mathrm{T}_{\min }\right.$, and $\left.\mathrm{T}_{\text {mean }}\right)$, precipitation, and relative humidity, both seasonally and annually, by using 36 years (1979-2014) of CSFR data from 16 stations placed around Punjab, Pakistan. The trends analyses were also undertaken for Punjab, Pakistan, as a whole. The major summary of this research is explained below:

- Seasonally, warming was more noticeable during the spring, with no or less precipitation. A significant $(p<0.05)$ trend was noticed for $\mathrm{T}_{\min }$ in spring and autumn in Punjab. Autumn precipitation also showed a significant $(p<0.05)$ trend in Punjab during 1979-2014.

- Annually, no significant trend was found for any of the variables studied, namely, $\mathrm{T}_{\max }, \mathrm{T}_{\min }, \mathrm{T}_{\text {mean }}$, precipitation, and relative humidity, in the Punjab province.

- Based on station-specific analyses, none of the stations showed a significant $(p<0.05)$ trend for annual precipitation or annual relative humidity. Similarly, all the stations showed non-significant $(p>0.05)$ trends for summer $\mathrm{T}_{\max }, \mathrm{T}_{\min }$, and $\mathrm{T}_{\text {mean }}$. 
- The prime focus of using the CS test was to analyze the monotonic tendency of the variables and the results showed all the variables were monotonic.

- After analyzing the station-specific data, many stations showed significant trends, but the most vulnerable were MB Din and TT Singh.

- The fluctuations in the HGT patterns were the root cause of the changing climate of Punjab, Pakistan, in many ways. In particular, we found that Punjab faced two drastic periods in recent years. One was a wet period, and the other was a dry period. The dry period (1999-2002) resulted in higher temperatures and low precipitation and humidity. In contrast, the wet period (2011-2014) was accompanied by low temperatures and high precipitation and humidity.

- Furthermore, the impact of anthropogenic activities on the variables that are associated with climate dynamics may be an interesting broad research topic that can be studied in the near future.

- To summarize, for the testing of our observations, more work is required. So far, our work covers a combination of assessments that focus on spatial and temporal heterogeneity, thresholds, and climate variability.

Author Contributions: A.S. and M.M. proposed the topic and X.L. modified the topic. A.S. and M.M. handled the data processing, data analysis, and wrote the whole manuscript. I.R., M.M., W.S., and X.L. helped with the enhancement of the research design, data analysis, interpretation, and manuscript writing. J.Z. and X.L. finalized the manuscript. H.O. reviewed and edited the manuscript. All authors read and agreed to the published version of the manuscript.

Funding: The International (Regional) Cooperation and Exchange Programs of National Natural Science Foundation of China (grant number 41961144019), National Key R\&D Program of China (grant number 2018YFC1508804), the Key Scientific and Technology Research and Development Program of Jilin Province (grant number 20180201033SF), the Major Scientific and Technological Program of Jilin Province (grant number 20200503002SF), the Key Scientific and Technology Program of Jilin Province (grant number 20170204035SF), and the Science and Technology Development Planning of Jilin Province (grant number 20190303081SF).

Institutional Review Board Statement: Not applicable.

Informed Consent Statement: Not applicable.

Data Availability Statement: Not applicable.

Acknowledgments: A.S. is deeply grateful to her supervisor Jiquan Zhang for his incredible support, specific guidelines, and emboldening. A.S. acknowledges the Climate Forecast System Reanalysis (CSFR) for the data availability. We appreciate the editors and the reviewers for their identically constructive comments and believe these suggestions have greatly improved the manuscript.

Conflicts of Interest: The authors have declared no conflict of interest.

\section{References}

1. Easterling, D.R.; Evans, J.L.; Groisman, P.Y.; Karl, T.R.; Kunkel, K.E.; Ambenje, P. Observed variability and trends in extreme climate events: A brief review. Bull. Am. Meteorol. Soc. 2000, 81, 417-426. [CrossRef]

2. Tabari, H.; Somee, B.S.; Zadeh, M.R. Testing for long-term trends in climatic variables in Iran. Atmos. Res. 2011, 100, 132-140. [CrossRef]

3. Stocker, T.F.; Qin, D.; Plattner, G.-K.; Tignor, M.M.; Allen, S.K.; Boschung, J.; Nauels, A.; Xia, Y.; Bex, V.; Midgley, P.M. Climate Change 2013: The Physical Science Basis Contribution of Working Group I to the Fifth Assessment Report of IPCC the Intergovernmental Panel on Climate Change; Cambridge University Press: Cambridge, UK, 2014.

4. New, M.; Todd, M.; Hulme, M.; Jones, P. Precipitation measurements and trends in the twentieth century. Int. J. Climatol. 2001, 21, 1889-1922. [CrossRef]

5. Jain, S.K.; Kumar, V.; Saharia, M. Analysis of rainfall and temperature trends in northeast India. Int. J. Climatol. 2013, 33, 968-978. [CrossRef]

6. Rasul, G.; Mahmood, A.; Sadiq, A.; Khan, S.I. Vulnerability of the Indus delta to climate change in Pakistan. Pak. J. Meteorol. 2012, 8, 89-107. 
7. Abbas, G.; Ahmad, S.; Ahmad, A.; Nasim, W.; Fatima, Z.; Hussain, S.; Rehman, M.H.; Khan, M.A.; Hasanuzzaman, M.; Fahad, S. Quantification the impacts of climate change and crop management on phenology of maize-based cropping system in Punjab, Pakistan. Agric. For. Meteorol. 2017, 247, 42-55. [CrossRef]

8. Bokhari, S.A.A.; Rasul, G.; Ruane, A.C.; Hoogenboom, G.; Ahmad, A. The past and future changes in climate of the rice-wheat cropping zone in Punjab, Pakistan. Pak. J. Meteorol. Vol. 2017, 13, 26.

9. Tariq, M.; Ahmad, S.; Fahad, S.; Abbas, G.; Hussain, S.; Fatima, Z.; Nasim, W.; Mubeen, M.; Rehman, M.H.; Khan, M.A. The impact of climate warming and crop management on phenology of sunflower-based cropping systems in Punjab, Pakistan. Agric. For. Meteorol. 2018, 256, 270-282. [CrossRef]

10. Chou, C.; Chiang, J.C.; Lan, C.-W.; Chung, C.-H.; Liao, Y.-C.; Lee, C.-J. Increase in the range between wet and dry season precipitation. Nat. Geosci. 2013, 6, 263-267. [CrossRef]

11. Jin, M.; Dickinson, R.E. New observational evidence for global warming from satellite. Geophys. Res. Lett. 2002, 29, 39-1-39-4. [CrossRef]

12. Shahid, S.; Harun, S.B.; Katimon, A. Changes in diurnal temperature range in Bangladesh during the time period 1961-2008 Atmos. Res. 2012, 118, 260-270. [CrossRef]

13. del Río, S.; Anjum Iqbal, M.; Cano-Ortiz, A.; Herrero, L.; Hassan, A.; Penas, A. Recent mean temperature trends in Pakistan and links with teleconnection patterns. Int. J. Climatol. 2013, 33, 277-290. [CrossRef]

14. Khan, N.; Shahid, S.; bin Ismail, T.; Wang, X.-J. Spatial distribution of unidirectional trends in temperature and temperature extremes in Pakistan. Theor. Appl. Climatol. 2019, 136, 899-913. [CrossRef]

15. Nashwan, M.S.; Shahid, S.; Wang, X. Uncertainty in estimated trends using gridded rainfall data: A case study of Bangladesh. Water 2019, 11, 349. [CrossRef]

16. Li, K.; Tong, Z.; Liu, X.; Zhang, J.; Tong, S. Quantitative assessment and driving force analysis of vegetation drought risk to climate change: Methodology and application in Northeast China. Agric. For. Meteorol. 2020, 282, 107865. [CrossRef]

17. Kabir, M.H.; Baten, M.A. Sustainability of Climate Change Adaptation Practices in South-Western Coastal Area of Bangladesh. J. Sustain. Dev. 2019, 12, 1-22. [CrossRef]

18. Sabziparvar, A.A.; Mir Mousavi, S.H.; Karampour, M.; Doostkamian, M.; Haghighi, E.; Rousta, I.; Olafsson, H.; Sarif, M.O.; Gupta, R.D.; Moniruzzaman, M. Harmonic Analysis of the Spatiotemporal Pattern of Thunderstorms in Iran (1961-2010). Adv. Meteorol. 2019, 2019. [CrossRef]

19. Field, C.B.; Barros, V.; Stocker, T.F.; Dahe, Q. Managing the Risks of Extreme Events and Disasters to Advance Climate Change Adaptation: Special Report of the Intergovernmental Panel on Climate Change; Cambridge University Press: Cambridge, UK, 2012.

20. Thomas, C.D.; Cameron, A.; Green, R.E.; Bakkenes, M.; Beaumont, L.J.; Collingham, Y.C.; Erasmus, B.F.; De Siqueira, M.F.; Grainger, A.; Hannah, L. Extinction risk from climate change. Nature 2004, 427, 145-148. [CrossRef]

21. Malhi, Y.; Roberts, J.T.; Betts, R.A.; Killeen, T.J.; Li, W.; Nobre, C.A. Climate change, deforestation, and the fate of the Amazon. Science 2008, 319, 169-172. [CrossRef]

22. Huber, D.G.; Gulledge, J. Extreme Weather and Climate Change: Understanding the Link, Managing the Risk; The Center for Climate and Energy Solutions (C2ES): Arlington, VA, USA, 2011.

23. Zhao, J.; Li, K.; Wang, R.; Tong, Z.; Zhang, J. Yield Data Provide New Insight into the Dynamic Evaluation of Maize's Climate Suitability: A Case Study in Jilin Province, China. Atmosphere 2019, 10, 305. [CrossRef]

24. Nashwan, M.S.; Shahid, S.; Chung, E.-S.; Ahmed, K.; Song, Y.H. Development of climate-based index for hydrologic hazard susceptibility. Sustainability 2018, 10, 2182. [CrossRef]

25. Ullah, S.; You, Q.; Ullah, W.; Ali, A. Observed changes in precipitation in China-Pakistan economic corridor during 1980-2016. Atmos. Res. 2018, 210,1-14. [CrossRef]

26. Khattak, M.S.; Babel, M.S.; Sharif, M. Hydro-meteorological trends in the upper Indus River basin in Pakistan. Clim. Res. 2011, 46, 103-119. [CrossRef]

27. Rahman, G.; Dawood, M. Spatial and temporal variation of rainfall and drought in Khyber Pakhtunkhwa Province of Pakistan during 1971-2015. Arab. J. Geosci. 2018, 11, 46. [CrossRef]

28. Ahmad, A.; Ashfaq, M.; Rasul, G.; Wajid, S.A.; Khaliq, T.; Rasul, F.; Saeed, U.; Rahman, M.H.; Hussain, J.; Ahmad Baig, I. Impact of climate change on the rice-wheat cropping system of Pakistan. In Handbook of Climate Change and Agroecosystems: The Agricultural Model Intercomparison and Improvement Project Integrated Crop and Economic Assessments, Part 2; Rosenzweig, C., Hillel, D., Eds.; Imperial College Press: London, UK, 2015; pp. 219-258.

29. Reggiani, P.; Mukhopadhyay, B.; Rientjes, T.H.M.; Khan, A. A joint analysis of river runoff and meteorological forcing in the Karakoram, upper Indus Basin. Hydrol. Process. 2017, 31, 409-430. [CrossRef]

30. Shirazi, S.A.; Zahid, F.; Bokhari, M.H. Rainfall variability and its impact on some selected crops of Punjab-Pakistan $1973-2003$. J. South Asian Stud. 2014, 22, 107-133.

31. Dow, K.; Berkhout, F.; Preston, B.L.; Klein, R.J.T.; Midgley, G.; Shaw, M.R. Limits to adaptation. Nat. Clim. Chang. 2013, 3, 305-307. [CrossRef]

32. Levin, S.A.; Clark, W. Toward a science of sustainability: Report from toward a science of sustainability conference. CID Work. Pap. Ser. 2010, 196. Available online: https://dash.harvard.edu/bitstream/handle/1/9774654/Clark-TowardScience.pdf?sequence= $1 \&$ isAllowed $=\mathrm{y}$ (accessed on 1 July 2021). 
33. Werners, S.E.; Pfenninger, S.; van Slobbe, E.; Haasnoot, M.; Kwakkel, J.H.; Swart, R.J. Thresholds, tipping and turning points for sustainability under climate change. Curr. Opin. Environ. Sustain. 2013, 5, 334-340. [CrossRef]

34. Iqbal, M.J.; Ali, M. A probabilistic approach for estimating return period of extreme annual rainfall in different cities of Punjab. Arab. J. Geosci. 2013, 6, 2599-2606. [CrossRef]

35. Aslam, A.Q.; Ahmad, I.; Ahmad, S.R.; Hussain, Y.; Hussain, M.S.; Shamshad, J.; Zaidi, S.J.A. Integrated climate change risk assessment and evaluation of adaptation perspective in southern Punjab, Pakistan. Sci. Total Environ. 2018, 628, 1422-1436. [CrossRef] [PubMed]

36. Khattak, M.S.; Ali, S. Assessment of temperature and rainfall trends in Punjab province of Pakistan for the period 1961-2014. J. Himal. Earth Sci. 2015, 48, 42.

37. Salma, S.; Rehman, S.; Shah, M.A. Rainfall trends in different climate zones of Pakistan. Pak. J. Meteorol. $2012,9,37-47$.

38. Jahangir, M.; Ali, S.M.; Khalid, B. Annual minimum temperature variations in early 21st century in Punjab, Pakistan. J. Atmos. Sol. Terr. Phys. 2016, 137, 1-9. [CrossRef]

39. Abbas, F. Analysis of a historical (1981-2010) temperature record of the Punjab province of Pakistan. Earth Interact. 2013, 17, 1-23. [CrossRef]

40. Li, L.; Zhang, R.; Wen, M. Structure characteristics of the vortices moving off the Tibetan Plateau. Meteorol. Atmos. Phys. 2020, 132, 19-34. [CrossRef]

41. Abbas, F.; Ahmad, A.; Safeeq, M.; Ali, S.; Saleem, F.; Hammad, H.M.; Farhad, W. Changes in precipitation extremes over arid to semiarid and subhumid Punjab, Pakistan. Theor. Appl. Climatol. 2014, 116, 671-680. [CrossRef]

42. Amin, A.; Nasim, W.; Mubeen, M.; Sarwar, S.; Urich, P.; Ahmad, A.; Wajid, A.; Khaliq, T.; Rasul, F.; Hammad, H.M. Regional climate assessment of precipitation and temperature in Southern Punjab (Pakistan) using SimCLIM climate model for different temporal scales. Theor. Appl. Climatol. 2018, 131, 121-131. [CrossRef]

43. Abid, M.; Scheffran, J.; Schneider, U.A.; Ashfaq, M. Farmers' perceptions of and adaptation strategies to climate change and their determinants: The case of Punjab province, Pakistan. Earth Syst. Dyn. 2015, 6, 225-243. [CrossRef]

44. Abid, M.; Schilling, J.; Scheffran, J.; Zulfiqar, F. Climate change vulnerability, adaptation and risk perceptions at farm level in Punjab, Pakistan. Sci. Total Environ. 2016, 547, 447-460. [CrossRef]

45. Hijmans, R.J.; Cameron, S.E.; Parra, J.L.; Jones, P.G.; Jarvis, A. Very high resolution interpolated climate surfaces for global land areas. Int. J. Climatol. 2005, 25, 1965-1978. [CrossRef]

46. Samie, A.; Deng, X.; Jia, S.; Chen, D. Scenario-based simulation on dynamics of land-use-land-cover change in Punjab Province, Pakistan. Sustainability 2017, 9, 1285. [CrossRef]

47. Didan, K.; Munoz, A.B.; Solano, R.; Huete, A. MODIS Vegetation Index User's Guide (MOD13 Series). University of Arizona: Vegetation Index and Phenology Lab; Version 3.00 (Collection 6). 2015. Available online: http://vip.arizona.edu/documents/ MODIS/MODIS_VI_UsersGuide_June_2015_C6.pdf (accessed on 1 July 2021).

48. Loveland, T.R.; Zhu, Z.; Ohlen, D.O.; Brown, J.F.; Reed, B.C.; Yang, L. An analysis of the IGBP global land-cover characterization process. Photogramm. Eng. Remote Sens. 1999, 65, 1021-1032.

49. Fowler, H.J.; Archer, D.R. Conflicting signals of climatic change in the Upper Indus Basin. J. Clim. 2006, 19, 4276-4293. [CrossRef]

50. Fedorová, D. Selection of unit root test on the basis of length of the time series and value of ar (1) parameter. Statistika 2016, 96, 3.

51. Gilbert, R.O. Statistical Methods for Environmental Pollution Monitoring; John Wiley \& Sons: Hoboken, NJ, USA, 1987.

52. Jaagus, J. Climatic changes in Estonia during the second half of the 20th century in relationship with changes in large-scale atmospheric circulation. Theor. Appl. Climatol. 2006, 83, 77-88. [CrossRef]

53. Cox, D.R.; Stuart, A. Some quick sign tests for trend in location and dispersion. Biometrika 1955, 42, 80-95. [CrossRef]

54. Vanya, C.L. Impact of Climate Variability and Change on Sorghum Production in the Lower Shire Valley in Malawi; University of Nairobi: Nairobi, Kenya, 2012.

55. Abeysingha, N.S.; Singh, M.; Sehgal, V.K.; Khanna, M.; Pathak, H. Analysis of trends in streamflow and its linkages with rainfall and anthropogenic factors in Gomti River basin of North India. Theor. Appl. Climatol. 2016, 123, 785-799. [CrossRef]

56. Wang, W.; Van Gelder, P.H.A.J.M.; Vrijling, J.K. Trend and stationarity analysis for streamflow processes of rivers in western Europe in the 20th century. In Proceedings of the IWA International Conference on Water Economics, Statistics, and Finance, Rethymno, Greece, 8-10 July 2005; pp. 8-10.

57. Dickey, D.A.; Fuller, W.A. Distribution of the estimators for autoregressive time series with a unit root. J. Am. Stat. Assoc. 1979, 74, 427-431.

58. Said, S.E.; Dickey, D.A. Testing for unit roots in autoregressive-moving average models of unknown order. Biometrika 1984, 71, 599-607. [CrossRef]

59. Zamani, R.; Mirabbasi, R.; Abdollahi, S.; Jhajharia, D. Streamflow trend analysis by considering autocorrelation structure, long-term persistence, and Hurst coefficient in a semi-arid region of Iran. Theor. Appl. Climatol. 2017, 129, 33-45. [CrossRef]

60. Partal, T. Wavelet transform-based analysis of periodicities and trends of Sakarya basin (Turkey) streamflow data. River Res. Appl. 2010, 26, 695-711. [CrossRef]

61. Chen, Y.; Guan, Y.; Shao, G.; Zhang, D. Investigating trends in streamflow and precipitation in Huangfuchuan Basin with wavelet analysis and the Mann-Kendall test. Water 2016, 8, 77. [CrossRef]

62. Yue, S.; Wang, C. The Mann-Kendall test modified by effective sample size to detect trend in serially correlated hydrological series. Water Resour. Manag. 2004, 18, 201-218. [CrossRef] 
63. Koutsoyiannis, D.; Montanari, A. Statistical analysis of hydroclimatic time series: Uncertainty and insights. Water Resour. Res. 2007, 43. [CrossRef]

64. Sen, P.K. Estimates of the regression coefficient based on Kendall's tau. J. Am. Stat. Assoc. 1968, 63, 1379-1389. [CrossRef]

65. Militino, A.F.; Moradi, M.; Ugarte, M.D. On the Performances of Trend and Change-Point Detection Methods for Remote Sensing Data. Remote Sens. 2020, 12, 1008. [CrossRef]

66. Farnsworth, D.L. A cautionary note concerning the Cox and Stuart test. Teach. Stat. 2001, 23, 76-79. [CrossRef]

67. Steinke, V.A.; Martins Palhares de Melo, L.A.; Luiz Melo, M.; Rodrigues da Franca, R.; Luna Lucena, R.; Torres Steinke, E. Trend Analysis of air Temperature in the Federal District of Brazil: 1980-2010. Climate 2020, 8, 89. [CrossRef]

68. Conover, W. Practical Nonparametric Statistics, 3rd ed.; John Wiley \& Sons: New York, NY, USA, 1999 ; Volume 578.

69. Wang, R.; Zhang, J.; Guo, E.; Zhao, C.; Cao, T. Spatial and temporal variations of precipitation concentration and their relationships with large-scale atmospheric circulations across Northeast China. Atmos. Res. 2019, 222, 62-73. [CrossRef]

70. Gupta, A.; Moniruzzaman, M. Spatio-Temporal Analysis of Changing Rainfall Pattern of Bangladesh Using Geo-Spatial Tools. In Proceedings of the International Conference on Weather Forecasting and Advances in Physics (CWFAP), Khulna, Bangladesh, 11-12 May 2018.

71. Kisi, O.; Ay, M. Comparison of Mann-Kendall and innovative trend method for water quality parameters of the Kizilirmak River, Turkey. J. Hydrol. 2014, 513, 362-375. [CrossRef]

72. Da Silva, R.M.; Santos, C.A.G.; Moreira, M.; Corte-Real, J.; Silva, V.C.; Medeiros, I.C. Rainfall and river flow trends using Mann-Kendall and Sen's slope estimator statistical tests in the Cobres River basin. Nat. Hazards 2015, 77, 1205-1221. [CrossRef]

73. Nawaz, Z.; Li, X.; Chen, Y.; Guo, Y.; Wang, X.; Nawaz, N. Temporal and Spatial Characteristics of Precipitation and Temperature in Punjab, Pakistan. Water 2019, 11, 1916. [CrossRef]

74. Iqbal, M.; Wen, J.; Wang, X.; Lan, Y.; Tian, H.; Anjum, M.N.; Adnan, M. Assessment of air temperature trends in the Source Region of Yellow River and its sub-basins, China. Asia-Pac. J. Atmos. Sci. 2018, 54, 111-123. [CrossRef]

75. Mitchell, J.M.; Dzerdzeevskii, B.; Flohn, H.; Hofmeyr, W.L.; Lamb, H.H.; Rao, K.N.; Wallén, C.C. Climatic change. Technical Note, No. 79. World Meteorol. Organ. Geneva Switz. 1966, 99, 79.

76. Ye, L. Hydrological Mann-Kendal multivariate trends analysis in the Upper Yangtze River basin. J. Geosci. Environ. Prot. 2015, 3 , 34. [CrossRef]

77. Guo, E.; Zhang, J.; Wang, Y.; Quan, L.; Zhang, R.; Zhang, F.; Zhou, M. Spatiotemporal variations of extreme climate events in Northeast China during 1960-2014. Ecol. Indic. 2019, 96, 669-683. [CrossRef]

78. Rutkowska, A. Properties of the Cox-Stuart test for trend in application to hydrological series: The simulation study. Commun. Stat. Simul. Comput. 2015, 44, 565-579. [CrossRef]

79. Akram, N.; Hamid, A. Climate change: A threat to the economic growth of Pakistan. Prog. Dev. Stud. 2015, 15, 73-86. [CrossRef]

80. Adams, R.M.; Hurd, B.H.; Lenhart, S.; Leary, N. Effects of global climate change on agriculture: An interpretative review. Clim. Res. 1998, 11, 19-30. [CrossRef]

81. Liu, Z.; Hubbard, K.G.; Lin, X.; Yang, X. Negative effects of climate warming on maize yield are reversed by the changing of sowing date and cultivar selection in Northeast China. Glob. Chang. Biol. 2013, 19, 3481-3492. [CrossRef]

82. Siebert, S.; Ewert, F. Spatio-temporal patterns of phenological development in Germany in relation to temperature and day length. Agric. For. Meteorol. 2012, 152, 44-57. [CrossRef]

83. Sheikh, M.M.; Manzoor, N. Region-wise Climate Changes in Pakistan (1951-2000). In Proceedings of the National Workshop on Global Change Perspective in Pakistan, Islamabad, Pakistan, 28-30 April 2005.

84. Zahid, M.; Rasul, G. Frequency of extreme temperature and precipitation events in Pakistan 1965-2009. Sci. Int. 2011, 23, 313-319.

85. Guna, A.; Zhang, J.; Tong, S.; Bao, Y.; Han, A.; Li, K. Effect of Climate Change on Maize Yield in the Growing Season: A Case Study of the Songliao Plain Maize Belt. Water 2019, 11, 2108. [CrossRef]

86. Merlone, A.; Al-Dashti, H.; Faisal, N.; Cerveny, R.S.; AlSarmi, S.; Bessemoulin, P.; Brunet, M.; Driouech, F.; Khalatyan, Y.; Peterson, T.C. Temperature extreme records: World Meteorological Organization metrological and meteorological evaluation of the $54.0 \mathrm{C}$ observations in Mitribah, Kuwait and Turbat, Pakistan in 2016/2017. Int. J. Climatol. 2019, 39, 5154-5169. [CrossRef]

87. Hussain, A.; Memon, J.A.; Hanif, S. Weather shocks, coping strategies and farmers' income: A case of rural areas of district Multan, Punjab. Weather Clim. Extrem. 2020, 30, 100288. [CrossRef]

88. Qasim, M.; Khlaid, S.; Shams, D.F. Spatiotemporal variations and trends in minimum and maximum temperatures of Pakistan. J. Appl. Environ. Biol. Sci. 2014, 4, 85-93.

89. Ullah, S.; You, Q.; Ali, A.; Ullah, W.; Jan, M.A.; Zhang, Y.; Xie, W.; Xie, X. Observed changes in maximum and minimum temperatures over China-Pakistan economic corridor during 1980-2016. Atmos. Res. 2019, 216, 37-51. [CrossRef]

90. Afzaal, M.; Haroon, M.A.; Zaman, Q. Interdecadal oscillations and the warming trend in the area-weighted annual mean temperature of Pakistan. Pak. J. Meteorol. 2009, 6, 13-19.

91. Ahmad, I.; Tang, D.; Wang, T.; Wang, M.; Wagan, B. Precipitation trends over time using Mann-Kendall and Spearman's rho tests in Swat River basin, Pakistan. Adv. Meteorol. 2015, 15, 2015. [CrossRef]

92. Ahmad, M.I.; Ma, H. Climate Change and Livelihood Vulnerability in Mixed Crop-Livestock Areas: The Case of Province Punjab, Pakistan. Sustainability 2020, 12, 586. [CrossRef] 
93. Rousta, I.; Nasserzadeh, M.H.; Jalali, M.; Haghighi, E.; Ólafsson, H.; Ashrafi, S.; Doostkamian, M.; Ghasemi, A. Decadal spatial-temporal variations in the spatial pattern of anomalies of extreme precipitation thresholds (Case Study: Northwest Iran). Atmosphere 2017, 8, 135. [CrossRef]

94. Price, J.D.; Wood, R. Comparison of probability density functions for total specific humidity and saturation deficit humidity, and consequences for cloud parametrization. Q. J. R. Meteorol. Soc. A J. Atmos. Sci. Appl. Meteorol. Phys. Oceanogr. 2002, 128, 2059-2072. [CrossRef]

95. da Silva, V.d.P.R. On climate variability in Northeast of Brazil. J. Arid. Environ. 2004, 58, 575-596. [CrossRef]

96. Xie, B.; Zhang, Q.; Ying, Y. Trends in precipitable water and relative humidity in China: 1979-2005. J. Appl. Meteorol. Climatol. 2011, 50, 1985-1994. [CrossRef]

97. Kousari, M.R.; Zarch, M.A.A. Minimum, maximum, and mean annual temperatures, relative humidity, and precipitation trends in arid and semi-arid regions of Iran. Arab. J. Geosci. 2011, 4, 907-914. [CrossRef]

98. Neil, K.; Wu, J. Effects of urbanization on plant flowering phenology: A review. Urban Ecosyst. 2006, 9, 243-257. [CrossRef]

99. Barry, R.G.; Chorley, R.J. Atmosphere, Weather and Climate; Routledge: London, UK, 2003.

100. Nebout, N.C.; Turon, J.; Zahn, R.; Capotondi, L.; Londeix, L.; Pahnke, K. Enhanced aridity and atmospheric high-pressure stability over the western Mediterranean during the North Atlantic cold events of the past 50 ky. Geology 2002, 30, 863-866. [CrossRef]

101. Asif, M. Climatic Change, Irrigation Water Crisis and Food Security in Pakistan; Uppsala Universitet: Uppsala, Sweden, 2013.

102. Bukhari, M.H.; Sayal, E.A. Emerging climate changes and water resource situation in Pakistan. Pak. Vis. 2011, 12, 236.

103. Siddiqui, R.; Samad, G.; Nasir, M.; Jalil, H.H. The impact of climate change on major agricultural crops: Evidence from Punjab, Pakistan. Pak. Dev. Rev. 2012, 51, 261-274. [CrossRef]

104. Shirazi, S.; Hussain, M.; Abbas, S.; Lee, S. Climate change impact on agriculture and prevalence of food security in Punjab, Pakistan. Pak. J. Sci. 2020, 72, 230.

105. McNeeley, S.M. Sustainable climate change adaptation in Indian country. Weather Clim. Soc. 2017, 9, 393-404. [CrossRef]

106. MacDonald, G.M. Water, climate change, and sustainability in the southwest. Proc. Natl. Acad. Sci. USA 2010, 107, 21256-21262. [CrossRef]

107. Ali, S.M.; Khalid, B.; Akhter, A.; Islam, A.; Adnan, S. Analyzing the occurrence of floods and droughts in connection with climate change in Punjab province, Pakistan. Nat. Hazards 2020, 103, 2533-2559. [CrossRef]

108. Dhakal, S.; Sedhain, G.K.; Dhakal, S.C. Climate change impact and adaptation practices in agriculture: A case study of Rautahat District, Nepal. Climate 2016, 4, 63. [CrossRef]

109. Sedhain, G.K.; Dhakal, S.; Dhakal, S.K.; Adhikary, R.K. Effects of changing precipitation patterns on agricultural practices of farmers in Rautahat, Nepal. Res. Briefs. 2016, 75. Available online: http://www.ncckmcnast.org.np/sites/default/files/ Research\%20Briefs\%20Building\%20Knowledge\%20for\%20Climate\%20Resilience\%20in\%20Nepal.pdf\#page=89 (accessed on 1 July 2021).

110. Wehbe, M.B.; Seiler, R.A.; Vinocur, M.R.; Eakin, H.; Santos, C.; Civitaresi, H.M. Social Methods for Assessing Agricultural Producers' Vulnerability to Climate Variability and Change Based on the Notion of Sustainability. Assessments of Impacts and Adaptations of Climate Change Working Papers. 2005. Available online: https:/ /www.semanticscholar.org/paper/SocialMethods-for-Assessing-Agricultural-to-and-on-Vinocur-Eakin/0128bf863878cfbca8e5f5c695eb6f3c473f2507 (accessed on 1 July 2021).

111. Mukhtar, U.; Zhangbao, Z.; Beihai, T.; Naseer, M.; Razzaq, A.; Hina, T. Implications of decreasing farm size on urbanization: A case study of Punjab Pakistan. J. Soc. Sci. Stud. 2018, 5, 71-86. [CrossRef]

112. Pakistan Bureau of Statistics. Provisional Province Wise Population by Sex \& Rural/Urban of 6th Population \& Housing Census of Pakistan; Pakistan Bureau of Statistics: 2017. Available online: https:/ /www.pbs.gov.pk/sites/default/files//Population_ Census_2017_Results_0.pdf (accessed on 1 July 2021).

113. Sajjad, S.; Shirazi, S.A.; Khan, M.A.; Raza, A. Urbanization effects on temperature trends of Lahore during 1950-2007. Int. J. Clim. Chang. Strateg. Manag. 2009, 1, 274-281. [CrossRef]

114. Stroik, P.; Chakraborty, D.; Ge, W.; Boulter, J.; Jamelske, E. Effect of reciprocity on public opinion of international climate treaties: Experimental evidence from the US and China. Clim. Policy 2019, 19, 959-973. [CrossRef]

115. EDGAR; European Commission; Netherlands Environmental Assessment Agency (PBL). Emission Database for Global Atmospheric Research (EDGAR), r.v.; 4.0. 2009. Available online: https:/ / edgar.jrc.ec.europa.eu/ (accessed on 1 July 2021).

116. Zuberi, M.J.S.; Ali, S.F. Greenhouse effect reduction by recovering energy from waste landfills in Pakistan. Renew. Sustain. Energy Rev. 2015, 44, 117-131. [CrossRef]

117. Hussain, M.; Butt, A.R.; Uzma, F.; Ahmed, R.; Rehman, A.; Ali, M.U.; Ullah, H.; Yousaf, B. Divisional disparities on climate change adaptation and mitigation in Punjab, Pakistan: Local perceptions, vulnerabilities, and policy implications. Environ. Sci. Pollut. Res. 2019, 26, 31491-31507. [CrossRef] [PubMed]

118. Shirazi, S.; Abbas, S.; Khurshid, M.; Shakarullah, K.; Yaseen, M.; Mazhar, N.; Wahla, S. Trends and variability of temperature time series over the kanshi catchment in the potohar region of punjab-pakistan. Pak. J. Sci. 2020, 72, 241-248.

119. Copeland, J.; McKelvey, K.; Aubry, K.; Landa, A.; Persson, J.; Inman, R.; Krebs, J.; Lofroth, E.; Golden, H.; Squires, J. The bioclimatic envelope of the wolverine (Gulo gulo): Do climatic constraints limit its geographic distribution? Can. J. Zool. 2010, 88, 233-246. [CrossRef] 
120. Neupane, M.; Dhakal, S. Climatic Variability and Land Use Change in Kamala Watershed, Sindhuli District, Nepal. Climate 2017, 5, 11. [CrossRef]

121. Yaqoob, H.; Teoh, Y.H.; Goraya, T.S.; Sher, F.; Jamil, M.A.; Rashid, T.; Yar, K.A. Energy evaluation and environmental impact assessment of transportation fuels in Pakistan. Case Stud. Chem. Environ. Eng. 2021, 3, 100081. [CrossRef]

122. Ghous, M.; Khalida, K.; Basit, A.; Hassan, J. Temporal analysis of urbanization and resulting local weather change: A case study of Lahore, Punjab, Pakistan. Sci. Int. 2015, 27, 1281-1287.

123. Van de Vliert, E.; Schwartz, S.H.; Huismans, S.E.; Hofstede, G.; Daan, S. Temperature, cultural masculinity, and domestic political violence: A cross-national study. J. Cross-Cult. Psychol. 1999, 30, 291-314. [CrossRef]

124. Cohen, J.L.; Furtado, J.C.; Barlow, M.; Alexeev, V.A.; Cherry, J.E. Asymmetric seasonal temperature trends. Geophys. Res. Lett. 2012, 39. [CrossRef]

125. Michaelowa, A. National Research Council, Abrupt Climate Change: Inevitable Surprises. Clim. Chang. 2004, 64, 377-380. [CrossRef] 